\title{
Correlation of the Upper Oligocene-Miocene deltaic to shelfal succession onshore Denmark with similar deposits in the northern North Sea and Norwegian Sea shelf based on $\mathrm{Sr}$ isotope-, bio- and seismic stratigraphy-a review
}

\author{
Tor Eidvin', Erik Skovbjerg Rasmussen², Fridtjof Riis', Karen Dybkjær ${ }^{2}$ \& Kari Grøsfjeld ${ }^{3}$ \\ ${ }^{1}$ Norwegian Petroleum Directorate (NPD), Professor Olav Hanssens vei 10, P. O. Box 600, NO-4003 Stavanger, Norway. \\ ${ }^{2}$ Geological Survey of Denmark and Greenland (GEUS), Øster Voldgade 10, DK-1350, Copenhagen K, Denmark. \\ ${ }^{3}$ Geological Survey of Norway, Leif Eirikssons vei 39, P. O. Box 6315 Torgarden, NO-7491 Trondheim, Norway
}

E-mail corresponding author (Tor Eidvin): tor.eidvin@npd.no

The almost complete, mainly deltaic, upper Paleogene and Neogene succession in Jylland, Denmark, was previously investigated for $87 \mathrm{Sr} / 86 \mathrm{Sr}$ ratios in 143 samples from 18 localities. In the present paper, strontium-isotope data from the Upper Oligocene-Lower Miocene parts and foraminiferal and pyritised diatoms data from 94 of these samples were used to correlate with previously published data from Norwegian wells and boreholes and one borehole in the British sector of the North Sea. For the Middle-Upper Miocene parts of the succession the correlation is based mainly on Bolboforma data. The ages of the geological formations in the Danish succession correlate readily with lithological units in the Norwegian North Sea, the Norwegian Sea shelf and the East Shetland Platform, which have all been investigated applying similar methods. The Bolboforma assemblages have their origin in the North Atlantic and the Norwegian Sea and confirm the presence of an open strait in the northern North Sea. This strait was the only seaway passage into the North Sea Basin during the Miocene. The glauconitic Utsira Formation sand (approximately 5.7-4.2 Ma), in the threshold area close to the outlet to the Norwegian Sea, overlies erosional unconformities comprising hiati of $21 \mathrm{my}$ in some areas and $13 \mathrm{my}$ in other areas. We believe that the unconformity below the Utsira Formation was mainly related to a fall in sea level in the Late Miocene, contemporaneous with that partly responsible for the Messinian salinity crisis. Bolboforma and dinoflagellate cysts stratigraphy indicate that the base of the Molo Formation in its southern distribution area (Draugen Field, Trøndelag Platform) is of Late Miocene age (close to $9 \mathrm{Ma}$ ). This part of the Molo Formation was contemporaneous with the middle/upper part of the Kai Formation.

Keywords: Sr isotope stratigraphy, foraminiferal stratigraphy, Bolboforma stratigraphy, upper Paleogene-Neogene correlation, Denmark, North Sea, Norwegian Sea shelf, Norwegian Sea.

Received 30. May 2019 / Accepted 25. September 2019 / Published online 30. October 2019

\section{Introduction}

A correlation between the well-dated outcropping Upper Oligocene-Miocene succession in Denmark (Eidvin et al., 2014a) and the offshore succession in the Norwegian North Sea, East Shetland Platform and Norwegian Sea shelf (Eidvin, 2016; Eidvin et al., 2013, 2014b) is a key for understanding the palaeogeography and infill history of the North Sea basin. A proper dating of the sedimentary units and recognition of the extent of hiatuses are necessary for this purpose.

Thin-walled calcareous microfossils such as foraminifera and Bolboforma are generally sparse in the Danish

Eidvin, T., Rasmussen, E.S., Riis, F., Dybkjær, K. \& Grøsfjeld, K. 2019: Correlation of the Upper Oligocene-Miocene deltaic to shelfal succession onshore Denmark with similar deposits in the northern North Sea and Norwegian Sea shelf based on Sr isotope-, bio- and seismic stratigraphy - a review. Norwegian Journal of Geology 99, 543-573. https://dx.doi.org/10.17850/njg99-4-1. 
onshore upper Paleogene and Neogene successions. This is either due to their dissolution by humic acid in the pore water or they were not present in the most marginal marine environments. However, from the stratigraphic borehole Rødding (DGU nr. 141.1141) in southern Jylland (Fig. 1), Eidvin et al. (2013) were able to retrieve foraminifera, Bolboforma and mollusc shells from most sections (Figs. 1 \& 2). In several sites, investigated for fossil dinoflagellate cysts (dinocysts) by Dybkjær \& Piasecki (2010), thick-walled tests of molluscs have been quite resistant to dissolution. These are present where foraminifera are absent, and Eidvin et al. (2014a) succeeded to retrieve molluscs and/or mollusc fragments from a number of samples for strontium isotope analyses from these sites (Table 1).
Eidvin et al. (2014a) presented a comparison and a discussion of the Danish strontium-isotope and dinocyst data. They concluded that the Sr isotope ages from the lower part of the Danish Miocene succession, i.e., the latest Oligocene-Early Miocene Brejning to Odderup formations, agree with the age estimates based on dinocysts. However, the ${ }^{87} \mathrm{Sr} /{ }^{86} \mathrm{Sr}$ ratios of fossil carbonates from the Middle-Upper Miocene, Hodde to Gram formations consistently indicate ages older than those recorded by the dinocysts (Fig. 2). Postdepositional processes as an explanation for this offset are inconsistent with the good preservation of the shell material. There is also restricted reworking. Eidvin et al. (2014a) suggested that limited oceanic exchange with the inner North Sea Basin might have caused the observed Sr isotope ratios.

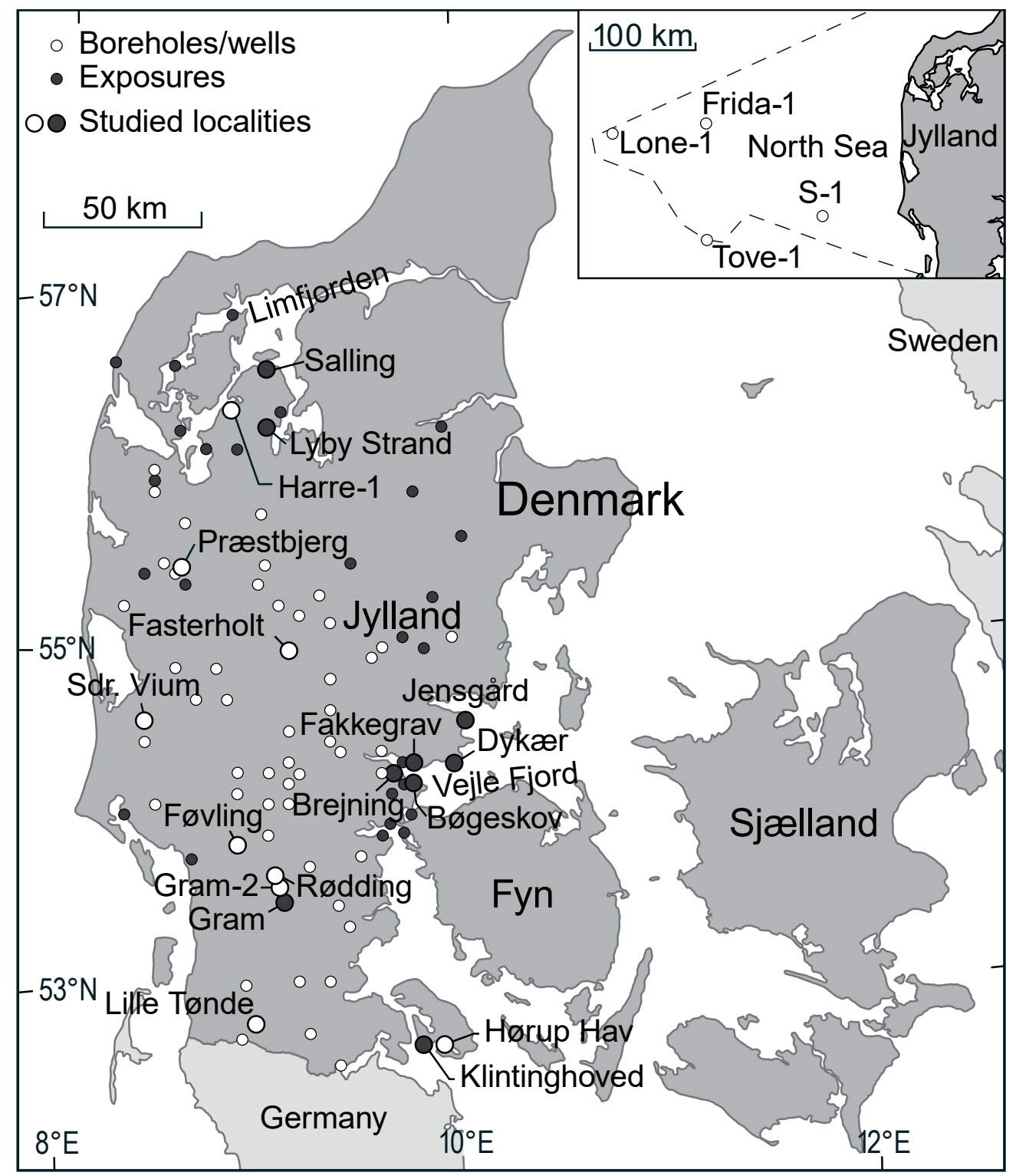

Figure 1. Map of onshore and offshore Denmark showing wells, boreholes and outcrops analysed for dinocysts (Dybkjor \& Piasecki, 2010), Bolboforma and foraminifera (Eidvin et al. 2013). It also shows the sites where shell material has been Sr dated. Small circles: Outcrops and boreholes which formed the basis for the dinocyst study (Dybkjor \& Piasecki, 2010). Large circles: Outcrops and boreholes that formed the basis for the dinocyst study (Dybkjoer \& Piasecki, 2010) as well as the present Sr isotope study. 


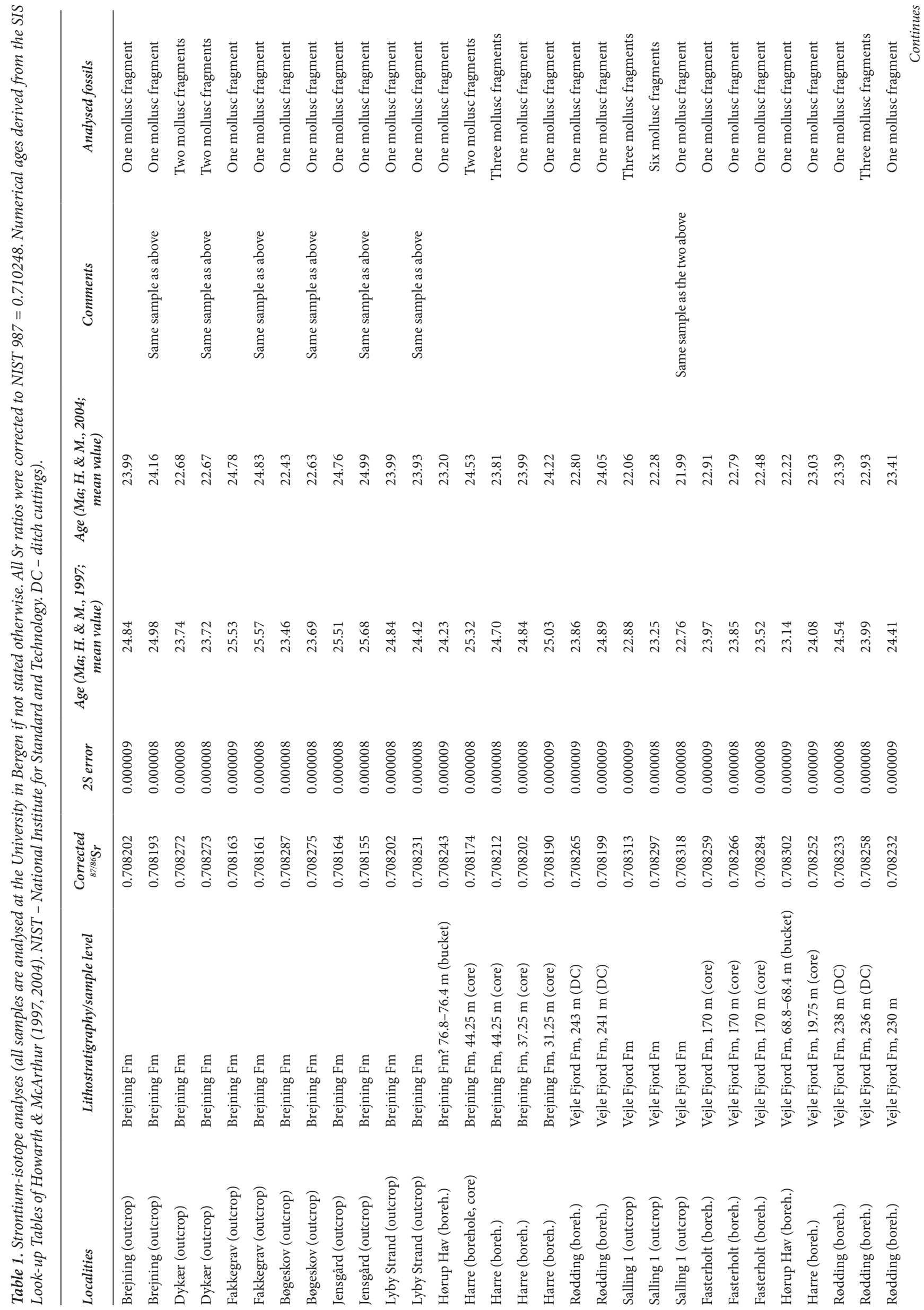




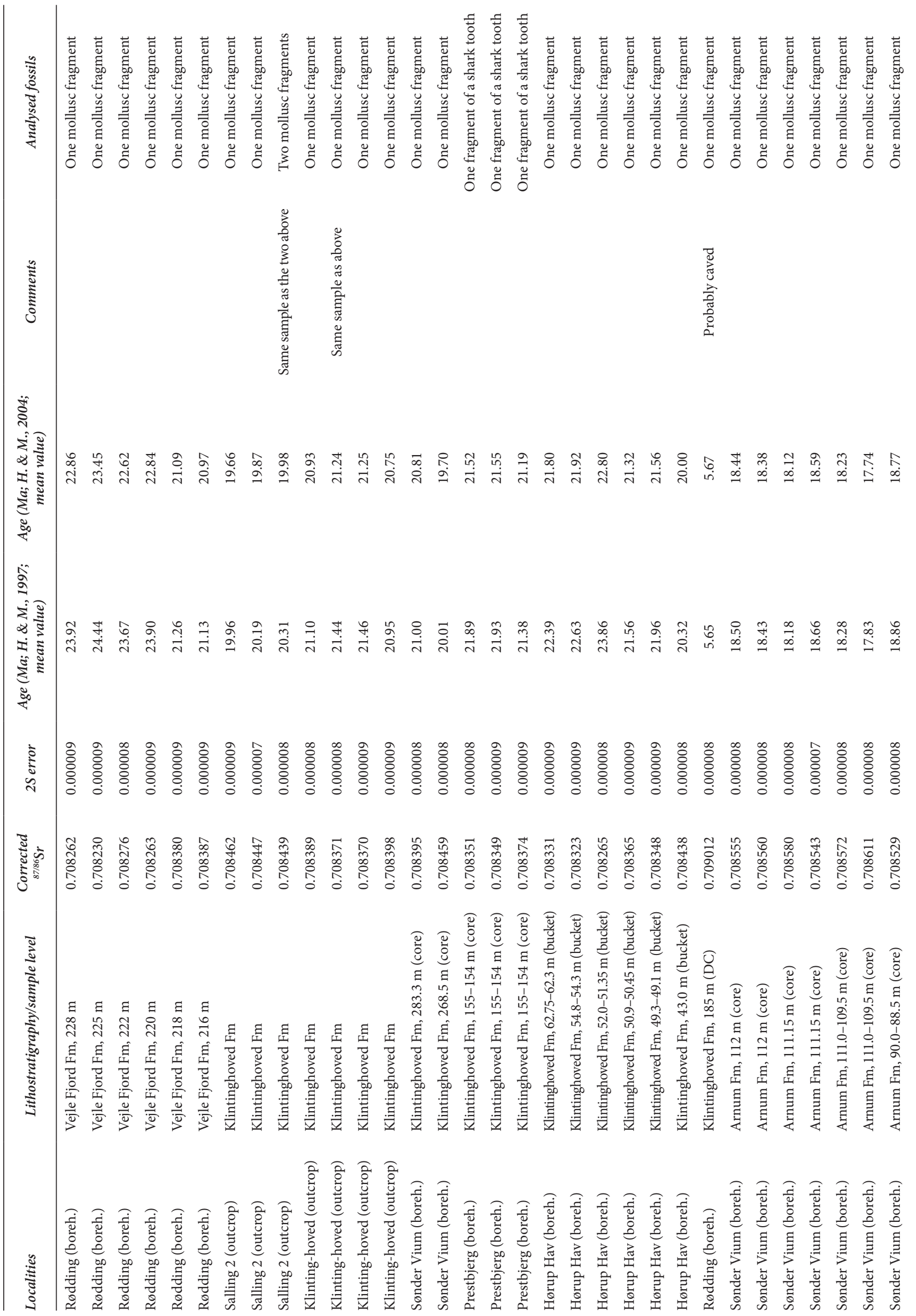




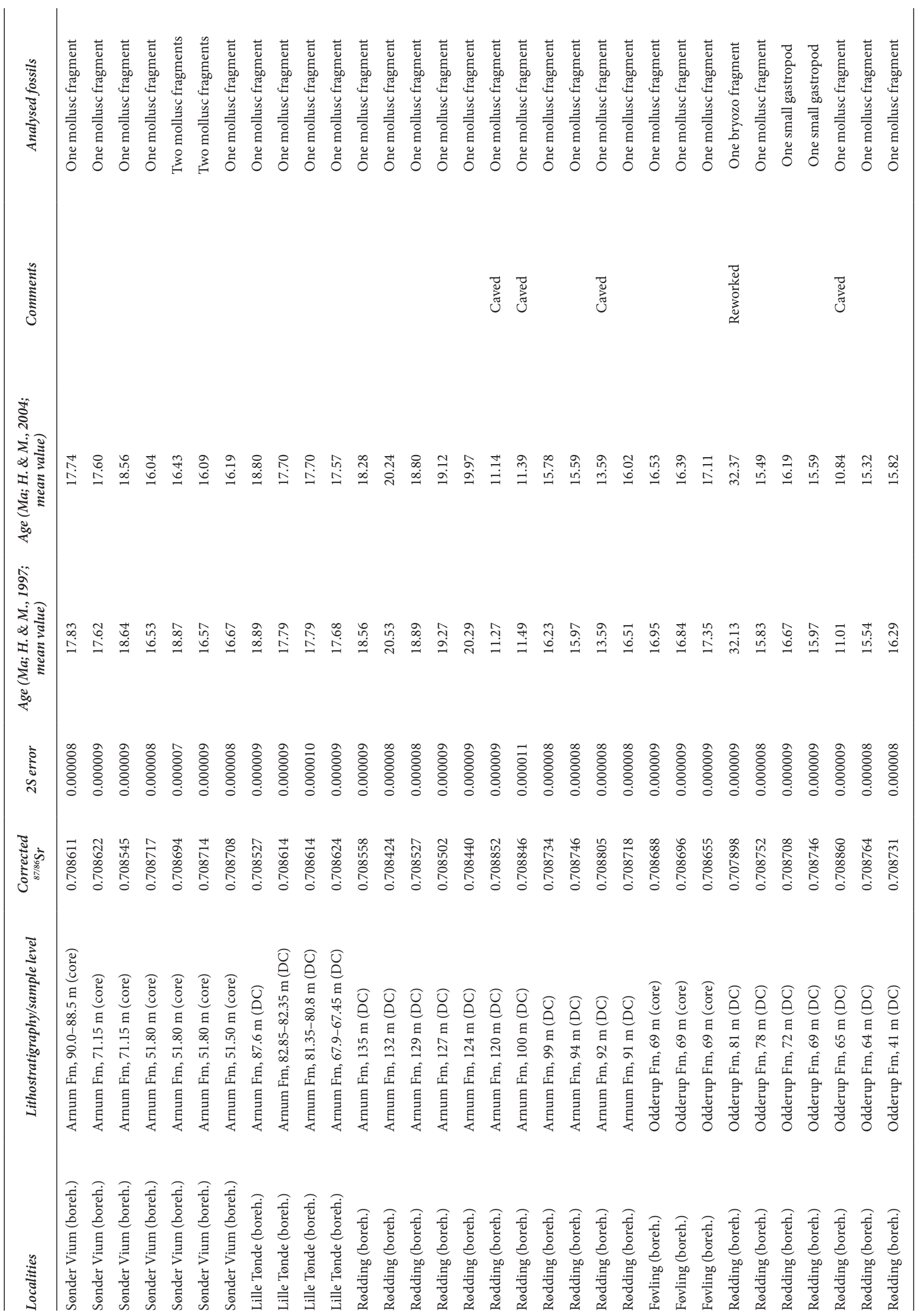


Table 2. Comparison of the Oligocene to Pleistocene time scale of Berggren et al. (1995) and Cohen et al. (2013, updated 2018). Please note that after Berggren et al. (1995), series/epochs, sub-series/sub-epochs and stages/ages are all formal chronostratigraphic units. After Cohen et al. (2013, updated 2018), series/epochs and stages/ages are formal chronostratigraphic units.

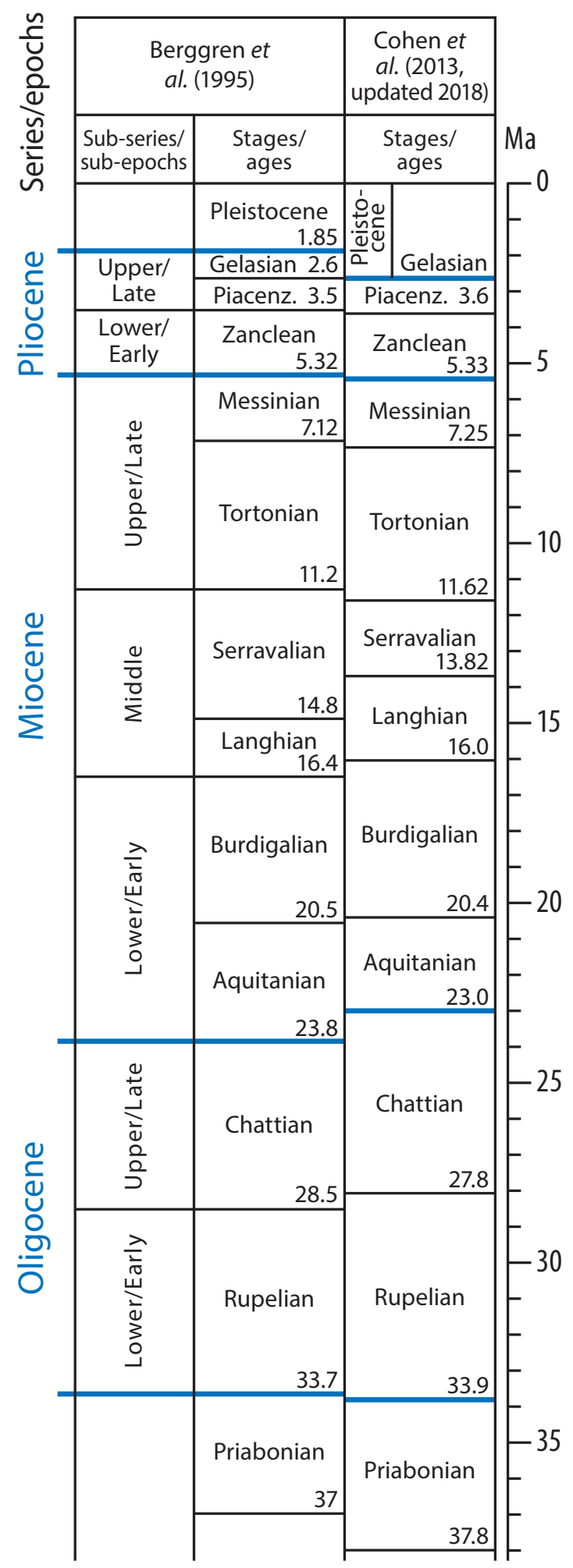

The purpose of the present paper is to correlate the data from the Danish succession (published in Eidvin et al., 2014a) with similar data in wells in the northern North Sea (Figs. 1-3; published in Eidvin, 2016 and Eidvin et al., 2013, 2014b). Since Eidvin et al. (2014a) showed that the strontium-isotope data from the Middle-Upper Miocene part of the Danish succession are not reliable and cannot be trusted, we have only used the strontium-isotope data from the Upper Oligocene-Lower Miocene part of this succession (Table 1). For the Middle-Upper Miocene part, the correlation is based on comparing the Bolboforma and foraminiferal assemblages in the Rødding borehole with similar assemblages in the Norwegian and British wells and boreholes and the deep-sea record (Figs. 4-8). Dinocyst correlation is also used in some areas. Eidvin et al. $(2013,2014 \mathrm{~b})$ have substantiated the approximate synchronicity of the upper Paleogene and Neogene delta and distal sediments in different parts of the North Sea (Figs. 9-12). In the present paper we present a more detailed correlation.

In a number of previous studies, more than 2000 samples, in more than 55 Norwegian wells and boreholes and one British well, have been analysed for benthic and planktonic foraminifera, Bolboforma and pyritised diatoms. As an additional control, and in order to increase the stratigraphic resolution, around 1500 samples from the same wells and boreholes, were analysed for ${ }^{87} \mathrm{Sr} /{ }^{86} \mathrm{Sr}$ ratios (Eidvin, 2016; Eidvin et al., 2013, 2014b). Most of the analysed samples were ditch cuttings, whereas sidewall cores and conventional core samples were available in some wells. Figures 1 and 2 in Eidvin et al. (2013) and figures 17 and 18 in Eidvin et al. (2014b) show the location of the analysed sidewall cores, conventional core samples and ditch cuttings. Caved material is often a problem when analysing ditch cuttings, whereas reworked material is always a problem regardless of types of samples. This is discussed in the papers where the detailed results of the analysis are presented (Eidvin, 2016; Eidvin \& Rundberg, 2007; Eidvin et al. 2007, 2013, 2014b and papers referred to in Eidvin et al. 2013, 2014b). These papers compare the ages provided by $\mathrm{Sr}$ isotope correlations with ages given by biostratigraphic correlations and discuss the uncertainties. In the northern North Sea, common soft-sediment deformation and sand injection in the lower part of the Utsira Formation, which are mainly restricted to the depocentres (Riis \& Eidvin, 2015, 2016), may also complicate the dating of the sediments. All wells have been tied to high-quality seismic data. The strontium data, which are used for the correlations in the present paper, are based on fossil tests interpreted to be in situ or having an age which does not deviate very much from the depositional age.

The ${ }^{87} \mathrm{Sr} /{ }^{86} \mathrm{Sr}$ ratios were converted to age estimates using the Strontium isotope stratigraphy (SIS) look-up 


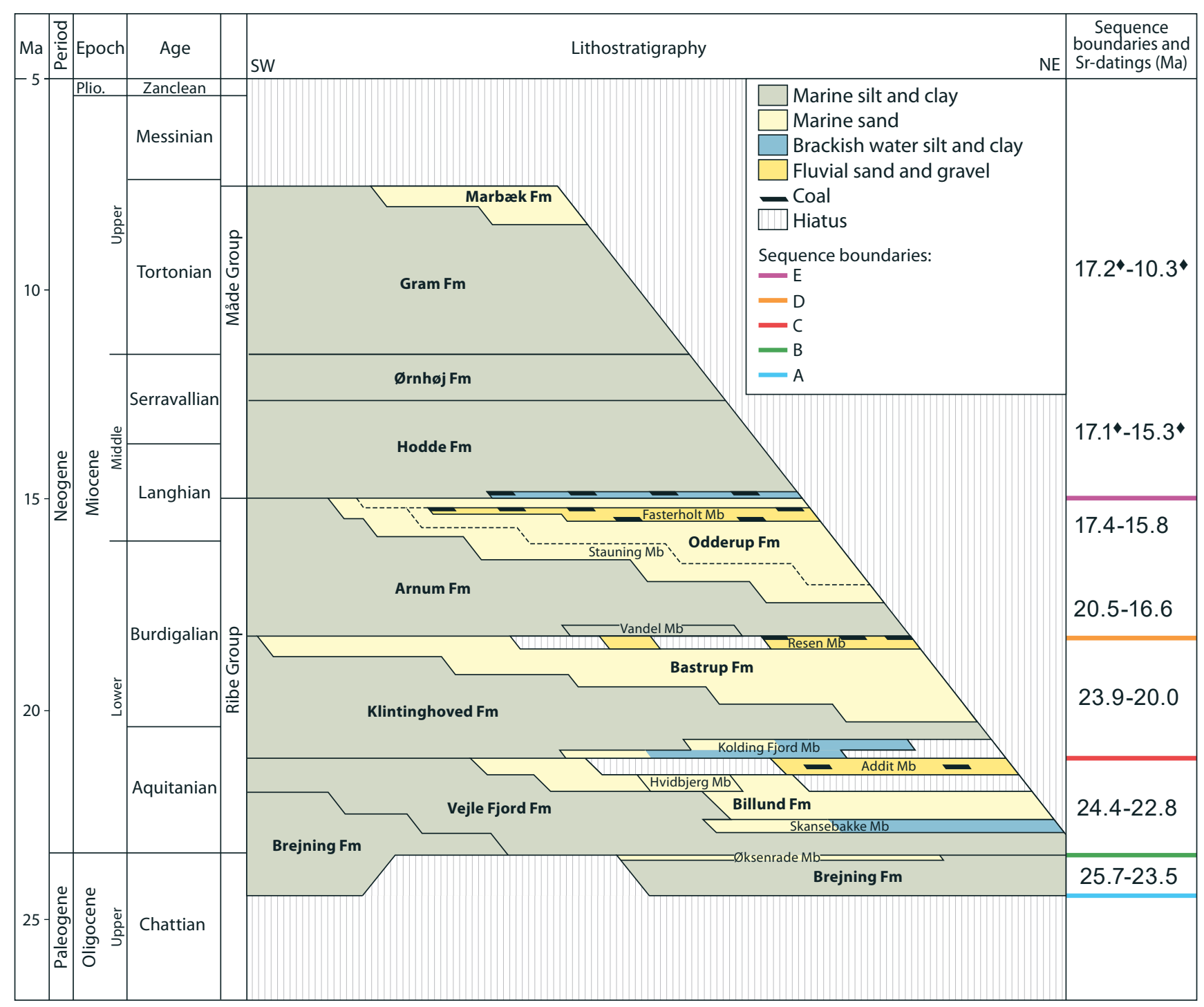

- = These ages are considerably older than the ages obtained from dinocyst correlations according to Eidvin et al. (2014a).

Figure 2. Lithostratigraphy of the Danish uppermost Oligocene-Miocene (from Rasmussen et al., 2010). The column to the right shows the palynological stratigraphy of Dybkjor \& Piasecki (2010) and the main results of the strontium-isotope datings of mollusc tests from outcrop and borehole samples. Please note that the stratigraphy of Rasmussen et al. (2010) and Dybkjoer \& Piasecki (2010) is based on the time scale of Gradstein et al. (2004). The strontium-isotope stratigraphy is based on the look-up table of Howarth \& McArthur (1997) which again is based on the time scale of Berggren et al. (1995). The use of Howarth \& McArthur's (1997) table is to facilitate correlation with successions on the Norwegian continental shelf. In the strontium-isotope analyses (Table 1), age estimates based on Howarth \& McArthur (2004) are also listed.

table of Howarth \& McArthur (1997; Eidvin et al., 2013, Fig. 3). Consequently, to facilitate correlation with successions on the Norwegian continental shelf, we have also converted the $\mathrm{Sr}$ ratios to age estimates using the same look-up table in the present paper. This look-up table is based on the time scale of Berggren et al. (1995), and this time scale is used throughout the present paper. The dinocyst zonation of Dybkjær \& Piasecki (2010) is based on the time scale of Gradstein et al. (2004). In the paper of Eidvin et al. (2014a) age estimates are based on the revised look-up table of Howard \& McArthur (2004), which in turn is based on the time scale of Gradstein et al. (2004). In the present paper, age estimates based on the tables of Howarth \& McArthur $(1997,2004)$ are listed (Table 1). There is currently no SIS look-up table that is based on the new time scale of Cohen et al. (2013, updated 2018). Table 2 shows that, for the post-Eocene, absolute ages for the time scales of Berggren et al. (1995) and Cohen et al. (2013, updated 2018) do not deviate very much. The most important difference is that in Cohen et al. (2013, updated 2018), the base Pleistocene is moved from 1.85 to $2.588 \mathrm{Ma}$. 


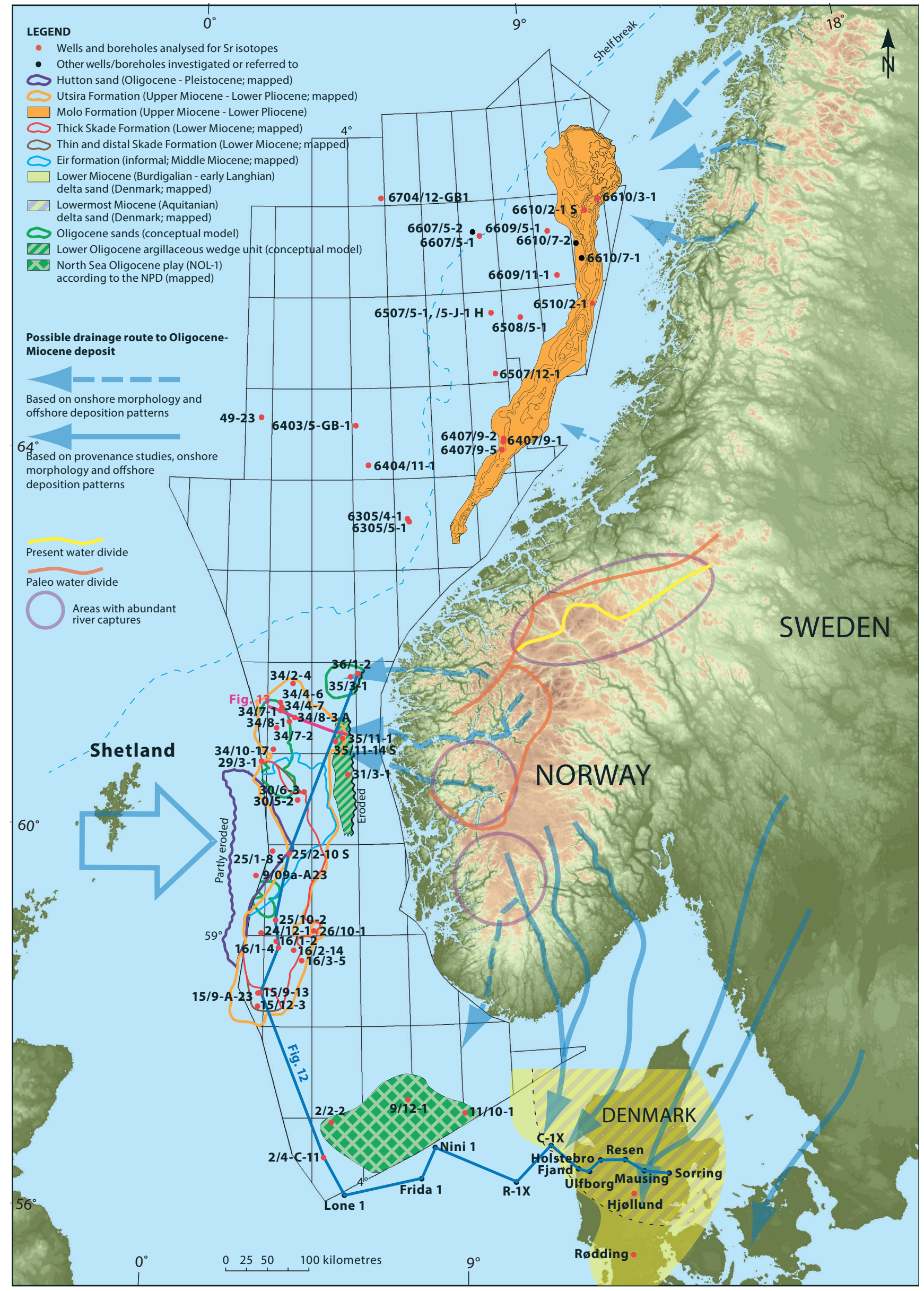


Figure 3. Map showing wells and boreholes containing Oligocene to Lower Pliocene deposits analysed for strontium isotopes, the location of the interpreted seismic profiles (Figs. 12 \&13) and the Oligocene to Lower Pliocene sandy deposits in the North Sea, Norwegian Sea and on the Norwegian Sea shelf mentioned in the text (the sites indicated in Figure 1 are not included; modified after Eidvin et al., 2013). The extent of the Oligocene sands and wedge units are according to Rundberg \& Eidvin (2005). The extent of the Utsira, Eir (informal) and Skade formations in the North Sea is according to the NPD (unpublished data). The extent of the Molo Formation is after Bullimore et al. (2005), and the extent of the Hutton sand (informal) is after Gregersen \& Johannessen (2007). The extent of the North Sea Oligocene play (NOL-1) is according to the Norwegian Petroleum Directorate web page (www.npd.no). The provenance study is after Olivarius (2009) and the topographic map is after Olesen et al. (2010).

\section{Geological setting}

The Norwegian-Danish Basin was formed during the Permian-Triassic rifting (Ziegler, 1982, 1990; Berthelsen, 1992). The basin is bounded to the northeast by the so-called Sorgenfrei-Tornquist Zone and the southern boundary is formed by the Ringkøbing-Fyn High. Reactivation of fault blocks took place in the Jurassic and especially salt movements were associated with the MidCimmerian tectonic phase (Vejbæk \& Andersen, 1987; Berthelsen, 1992; Thybo, 2001). Regional subsidence characterised the basin from the Early Cretaceous. This period was still dominated by a paralic depositional setting. During the Late Cretaceous, inversion of former graben structures occurred, and resumed reactivation of salt structures probably commenced (Mogensen \& Korstgård, 1993). The Late Cretaceous period was dominated by deposition of marine chalk, and adjacent to the Sorgenfrei-Tornquist Zone a 1-2 km-thick succession of chalk was formed. However, in the marginal areas of the Fennoscandian Shield, e.g. Scania, uplift of basement resulted in progradation of siliciclastic delta systems (Erlström, 1994). Continued subsidence in the North Sea characterised the Paleogene. Marine chalk, and later on marine clay, accumulated in the basin. Along the Sorgenfrei-Tornquist Zone, minor uplift/inversion of the flanks occurred in the Late Paleocene (Nielsen et al., 2005). Deposition of marine clay continued into the Eocene. Minor reactivation of salt structures commenced at the Eocene/Oligocene boundary. From the Oligocene, mud-dominated, mica-rich, marine sediments were deposited. During the latest Early Oligocene, sandy deltaic deposits started to accumulate in the northeastern part of the basin in the Norwegian sector of the North Sea (Eidvin et al., 2013). The change from clay-dominated to mud- and sand-dominated, mica-rich sediments was associated with progradation of sediments sourced in the Southern Scandes. Inversion of the Norwegian-Danish Basin took place at the Oligocene-Miocene boundary (Rasmussen, 2009, 2013). Early Miocene uplift of the Southern Scandes and a decreasing water depth in the Norwegian-Danish basin resulted in progradation of sand-rich deltaic deposits in the eastern North Sea Basin throughout this period. During the Middle Miocene, the regional subsidence of the central North Sea Basin accelerated while the basin flanks became uplifted (Ziegler, 1990; Knox et al., 2010; Rasmussen \& Dybkjær, 2014). In Denmark, this resulted in flooding of the margins and deposition of marine mud on top of the Lower Miocene deltaic deposits. Resumed delta progradation took place during the Late Miocene (Sørensen et al., 1997), and at this time the deltas reached the central part of the Danish North Sea Basin (Rasmussen et al., 2005, 2008). The Norwegian-Danish Basin was probably a land area during the Pliocene. However, the evidence for that has been destroyed by Quaternary uplift and erosion (Japsen, 1993).

The North Sea Basin is an epicontinental basin, confined by the Scandinavian and British landmasses, with a marine connection in the north to the NorwegianGreenland Sea (Figs. $3 \&$ 8). In the Norwegian sector, the basin comprises several major, Mesozoic highs and grabens of which the Central Graben in its south-central region and the Viking Graben in the north are dominant (see figure 7 in Eidvin et al., 2013 or figure 15 in Eidvin et al. 2014b). Tectonism ceased in the Cretaceous and the basin was subjected to post-rift subsidence and became filled by sediments sourced by the surrounding topographical highs. In the Paleocene-Eocene, the surrounding landmasses were uplifted and the North Sea Basin deepened. Deltaic sequences prograded into the deep basin from the Shetland Platform and West Norway. Progradation continued in the Oligocene and Miocene, but the source area was then mainly confined to the Shetland Platform (Eidvin \& Rundberg, 2001, 2007; Gregersen \& Johannessen, 2007; Rundberg \& Eidvin, 2005; Eidvin et al., 2013). The depocentres typically contain $200-600 \mathrm{~m}$ of Oligocene to Lower Pliocene sands.

The Norwegian Sea and its continental shelf and slope contain various structural elements (see figure 6 in Eidvin et al., 2013 or figure 10 in Eidvin et al., 2014b). The Møre and Vøring basins are characterised by exceptionally thick Cretaceous successions and a complex Cretaceous and Cenozoic tectonic history (Blystad et al., 1995; Brekke, 2000). In Oligocene to Early Pliocene times, the Møre and Vøring basins were located in a distal position relative to sediment supply from Scandinavia, and pelagic ooze makes up a significant part of the succession. Large compressional structures were formed during Eocene and Middle Miocene tectonism. The Trøndelag Platform has remained tectonically stable since the Late Cretaceous. In the Late Miocene to Early Pliocene, there was a pronounced progradation of coastal sediments along the inner Norwegian Sea continental shelf (represented by the sandy Molo Formation, typically 100-200 m thick). Farther west on the present continental shelf, deposition of fine-grained clastic sediment and pelagic ooze prevailed, and contouritic deposits are common (Laberg et al., 2005). 


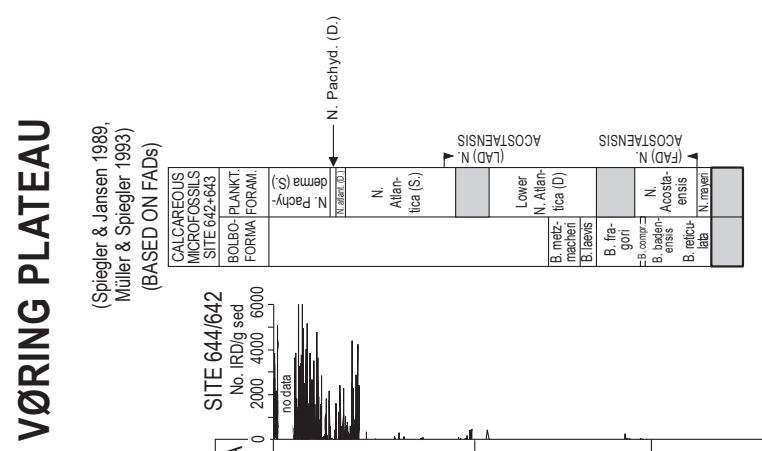

ฐँ ฐ

흘 से

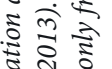

离学胥

के

당

之 신

बे है

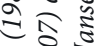

\&

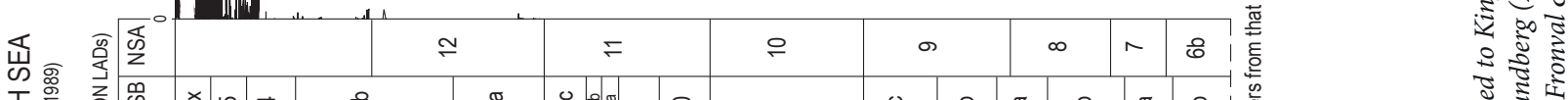

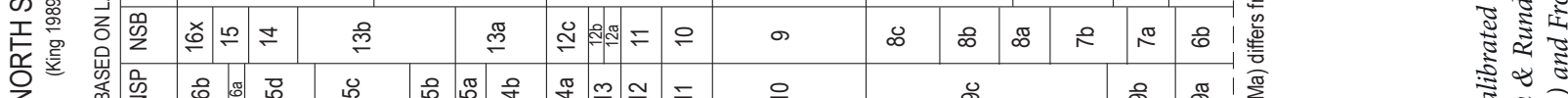

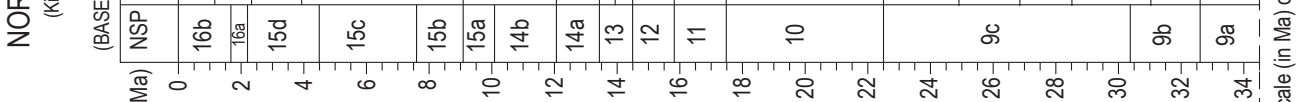

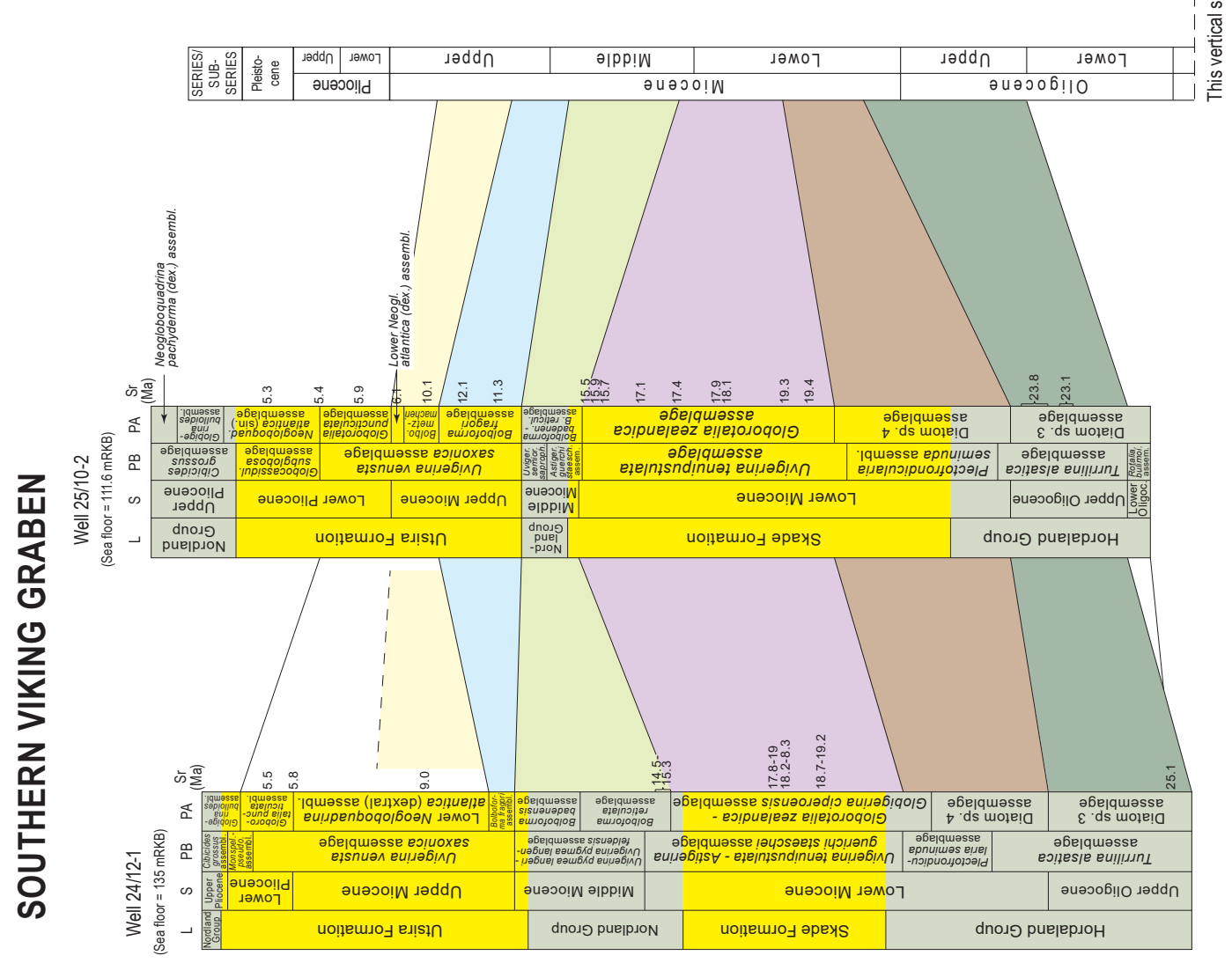

ह इ

은 준

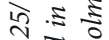

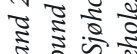

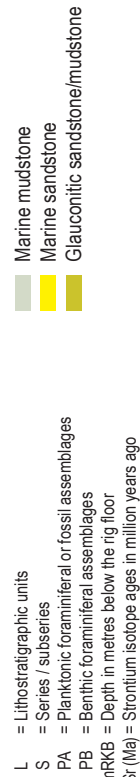

जक

ป

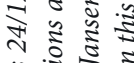

च

क : का

:

कू

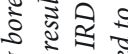

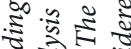

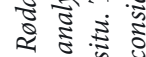

₹ $: 5$

จ

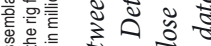

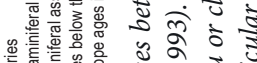

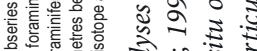

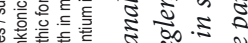

के कू

के क्ष

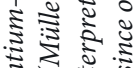

을

के

0.5

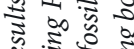

$=5:$

इ ะ

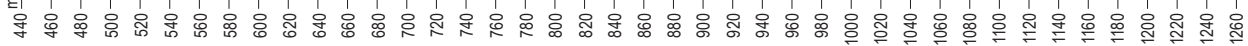

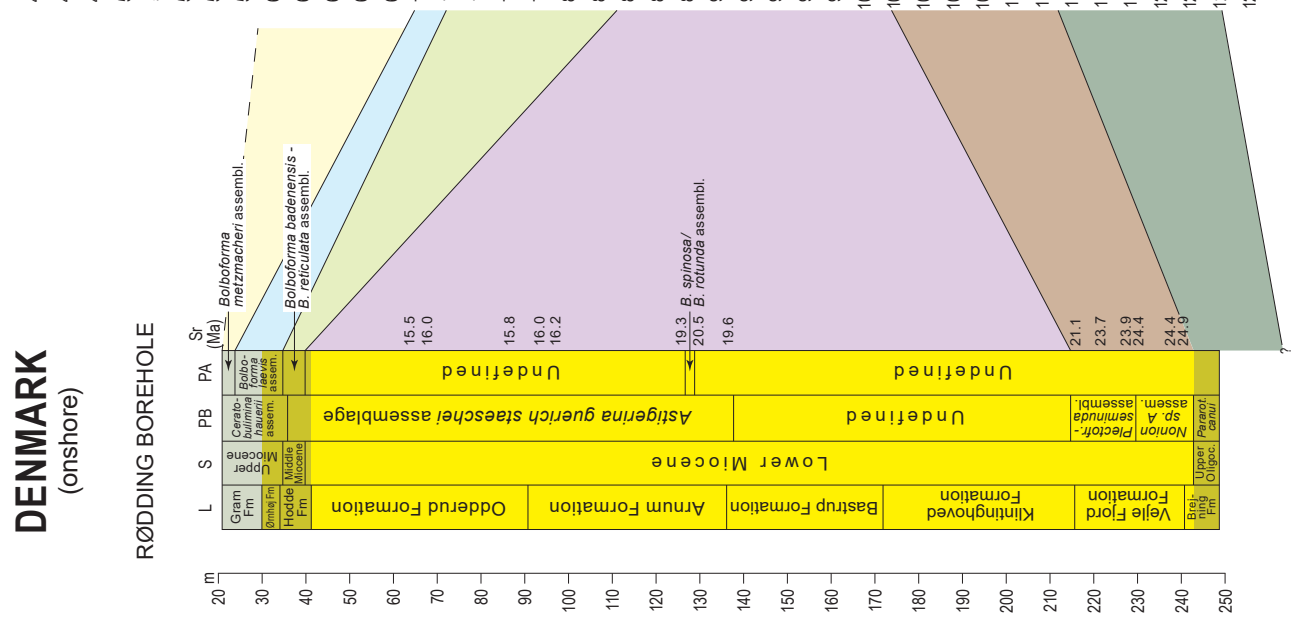

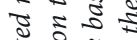

تृ

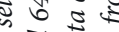

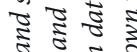

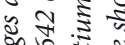

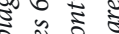

范落

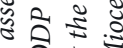

至

s.

ㄴ.

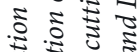

돌 हू

ㅎํํㅎำ

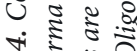

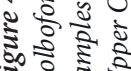




\section{Palaeoclimate}

The global deep-sea $\delta^{18} \mathrm{O}$ record shows that a cool climate prevailed early in the Late Oligocene, but a warming trend started in the later part of Late Oligocene (Fig. 9). This warming trend is also detected in NW Europe (Utescher et al., 2009; Larsson et al, 2011); consequently, a warm temperate and humid climate persisted in the North Sea realm during the Oligocene. This warm climate continued during the Early Miocene. The mean annual temperature was 19 to $20^{\circ} \mathrm{C}$ and the winters were frost free. The precipitation was in the order of 1300 to $1500 \mathrm{~mm}$ per year (Utescher et al., 2009; Larsson et al., 2010, 2011; Rasmussen, 2013). Minor deteriorations in climate, the so-called Mi events (glaciation events in Antarctica; Miller et al., 1998), resulted in short-spanned decreases in air temperature in the order of $2-5^{\circ} \mathrm{C}$ (Larsson et al., 2010, 2011; Sliwinska et al., 2014). The global mid Miocene Climatic Optimum apparently did not have any distinct influence on the air temperature in the Danish North Sea area (Larsson et al., 2011). In the Late Miocene and Pliocene, a minor climatic deterioration occurred in Central Europe (Utescher et al., 2009), but in southern Scandinavian this decline is not observed during the Late Miocene (Larsson et al., 2011). Data from Central England also indicate that a relatively warm climate persisted during the Late Miocene (Pound \& Riding, 2015). Also on Iceland, a warm temperate, humid climate existed during the mid to early Late Miocene, with a shift to a cool temperate climate during the latest Late Miocene (Denk et al., 2005).

A study of continuous late Neogene sediment sections from ODP Site 907 on the Iceland Plateau and ODP Sites 642, 643 and 644 on the Vøring Plateau (Norwegian Sea; Fig. 8) showed a gradual and stepwise cooling of the deep water of the Iceland-Norwegian Sea with major cooling events at approximately 11 and $6.4 \mathrm{Ma}$ (Fronval \& Jansen, 1996). The oldest ice-rafted debris (IRD) detected is dated to approximately $12.6 \mathrm{Ma}$. IRD from this event is also recorded in borehole 6704/12-GB1 on the Vøring Plateau (Fig. 3; Eidvin et al., 1998, 2013). This coincides with a decrease in mean annual temperature at middle and high latitudes, an intensification of North Atlantic deep-water production, and a change in circulation patterns within the Iceland-Norwegian Sea, as indicated by a shift from extensive biogenic opal ooze deposition to carbonate accumulation on the Vøring Plateau. IRD records from both the Iceland Plateau and the Vøring Plateau suggest further intensifications of the Northern Hemisphere glaciations at approximately $6 \mathrm{Ma}$ (Messinian). The onset of the large-scale Northern Hemisphere glaciations is dated to $2.75 \mathrm{Ma}$ on the Vøring Plateau and 2.9 $\mathrm{Ma}$ on the Iceland Plateau (Fronval \& Jansen, 1996). The different timing could imply that the growth of the large ice sheets did not occur simultaneously in Greenland and Scandinavia. There is no evidence for the existence of glaciers along the eastern seaboard of the Norwegian-Greenland Sea before 2.75 Ma (Fronval \& Jansen, 1996).

\section{Description of correlated areas and deposits}

\section{Overview}

The depocentre in the Norwegian-Danish Basin and Jylland (the eastern North Sea Basin) received sediments from the Southern Scandes mountains, with a general progradation from north to south during the period. The depocentre in the basinal areas of the UK and Norwegian sectors of the North Sea, north of $58^{\circ} \mathrm{N}$, received sediments from the Scotland-Shetland area. Because of the sedimentary infilling there was a gradual shallowing of the northern North Sea basin in the Oligocene to the Pliocene. In other local depocentres along the coast of Norway, deposition of sandy sediments took place only occasionally (Eidvin et al., 2013).

\section{Onshore Denmark (eastern North Sea Basin)}

In Jylland, Denmark, large areas have upper Paleogene and Neogene successions below the Quaternary glacial deposits. The Lower Miocene succession is characterised by coarse-grained, dominantly sand-rich, fluvio-deltaic deposits interfingering with marine clay (Larsen \& Dinesen 1959; Rasmussen \& Dybkjær, 2005; Hansen \& Rasmussen, 2008; Rasmussen et al., 2010). The delta was sourced from the Southern Scandes in Norway and Central Sweden and prograded towards the south and southwest (Figs. $3 \& 8$ ). The deltaic succession, referred to the Ribe Group, is composed of three discrete units referred to sequences B, C and D by Rasmussen (2004) and is approximately $200 \mathrm{~m}$ thick with a gross thickness of sand up to $150 \mathrm{~m}$. The abrupt incursion of sand in the southern part of the Norwegian-Danish Basin in the earliest Miocene is interpreted to be the result of an inversion of the basin and a possible coincident uplift of the source area. The Ribe Group is succeeded by the muddominated Måde Group (Lower Nordland Group). The Måde Group was deposited in a fully marine depositional setting that lasted from Middle-Late Miocene time in the eastern North Sea Basin. Onshore, the Måde Group is up to $140 \mathrm{~m}$ thick and is subdivided into three sequences; $\mathrm{E}$, F1 and F2 (Møller et al., 2009; Rasmussen, 2017).

These deposits have been studied palynologically in more than fifty boreholes (including some offshore boreholes) and about twenty-five outcrops (Fig. 1). Dinocysts occur in nearly all of the deposits. The palynological studies have resulted in a dinocyst zonation scheme of nineteen dinocyst zones spanning from the Oligocene-Miocene transition to the Pliocene (Dybkjær \& Piasecki, 2010). 


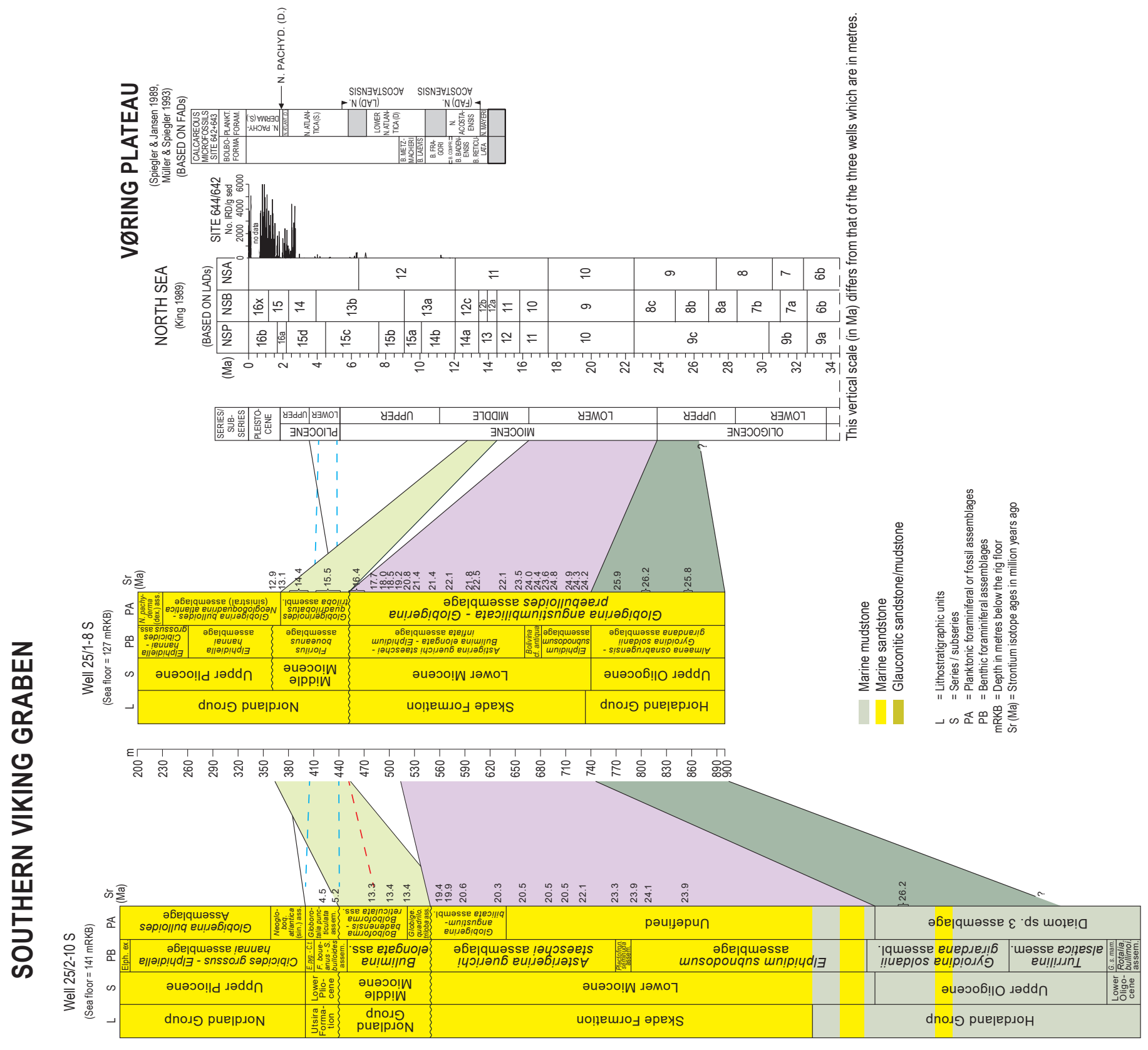

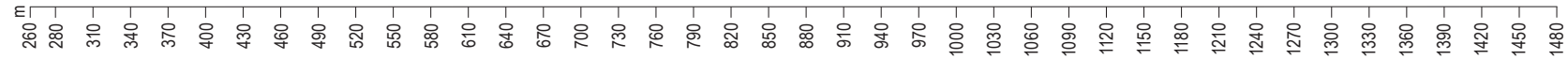

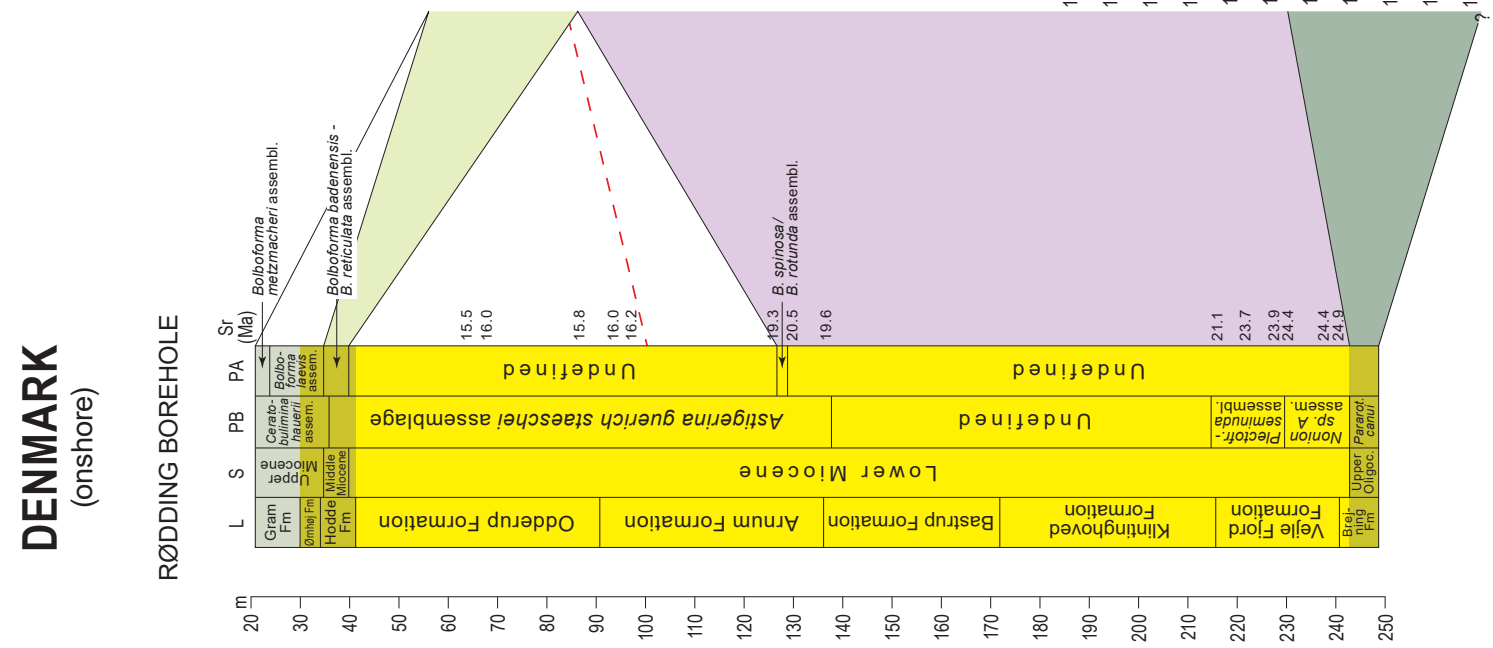


Figure 5. Correlation of fossil assemblages and selected, main results of strontium-isotope analyses between the Rødding borehole and wells 25/2$10 S$ and 25/1-8 S calibrated to King's (1989) North Sea zonation and the Bolboforma zonation of the ODP Sites 642 and 643 on the Vøring Plateau (Müller \& Spiegler, 1993). Detailed analysis results and discussions are found in Eidvin \& Rundberg (2007) and Eidvin et al. (2013). All the samples are ditch cuttings, but the strontium data are based on fossil tests interpreted to be in situ or close to in situ. The IRD curve is after Jansen \& Sjøholm (1991) and Fronval \& Jansen (1996). Sr data only from the Upper Oligocene and Lower Miocene are shown from the Rødding borehole, since only these particular data are considered to be reliable from this borehole.

\section{Central and northern North Sea}

According to Eidvin et al. (2013), during late Rupelian to Chattian, sediments in the northernmost part of the North Sea Basin were sourced from the northwestern part of the South Scandes Dome, which was a topographic high throughout the Paleogene. In the northeastern part of the northern North Sea off Nordfjord, sandy gravity-flow sediments were deposited (Ull formation, an informal name suggested by Eidvin et al., 2013). Farther south off Hordaland and Sogn and Fjordane, a distinct wedge of Rupelian organic-rich mudstones was formed along the coast. Deltaic complexes prograded southwards into the Norwegian-Danish Basin (Vade Formation and the sand-rich part of the Lark Formation, and the Dufa and Freja members in Danish waters). In the latest Rupelian to Chattian there was a large input of sandy sediments from the Shetland Platform into the northern North Sea. Most of the sediments were laid down in the southern Tampen area (the informal Ull formation). Farther south, Chattian deposits are recorded below the Skade Formation in the Frigg Field area, i.e., within the area belonging to the Hutton Sand according to Gregersen \& Johannessen (2007). Elsewhere, in the central and northern North Sea, mainly argillaceous sediments were deposited.

In large parts of the Viking Graben (northern North Sea), a sandy section, sourced from the East Shetland Platform, makes up a great proportion of the Lower Miocene Skade Formation. More than 500 exploration wells have penetrated the Lower Miocene deposits, and selected wells have been investigated for benthic and planktonic foraminifera, pyritised diatoms and ${ }^{87} \mathrm{Sr} /{ }^{86} \mathrm{Sr}$ ratios (marked with red dots in Fig. 3; Eidvin et al., 2013). One well from the East Shetland Platform, in the British North Sea sector, has also been investigated (Eidvin, 2016). The Skade Formation reaches a maximum thickness of up to $400 \mathrm{~m}$ (Eidvin et al., 2013). In the British sector, the Lower Miocene sandy deposits constitute a part of the Hutton sand succession. Hutton sand is an informal term used in the UK sector by several oil companies to describe all sands above the Lower Eocene Balder Formation in the Northern North Sea (British Geological Survey, 2000). The Skade Formation comprises a succession of amalgamated sands in alternation with thinner mudstones. In most parts, the deposits are probably turbiditic in origin and were probably deposited in quite deep parts of the shelf. The sandy successions in the wells 25/2-10 S and 25/1-8 S and the British well 9/09a-A 23 (Fig. 3) contain common mollusc fragments and lignite coal and have probably been deposited in mainly shallow water (Eidvin et al., 2013; Eidvin, 2016). All of these wells are situated within the deltaic Hutton sand area as defined by Gregersen \& Johannessen (2007). As seen in figure 3, the Hutton sand extends into the Norwegian sector and continues into the deeper water Skade Formation. The Skade sands pinch out towards the lower slope of the Norwegian margin to the east. It has been suggested that the sandy deposits are a result of an Early Miocene tectonic uplift event affecting the East Shetland Platform, possibly associated with a renewed compressional tectonic phase along the northwestern European margin (Rundberg \& Eidvin, 2005).

During the Middle Miocene, sediments continued to be deposited from the East Shetland Platform. In the northern North Sea, these deposits form a part of the Hutton sand succession in the UK sector and represent the basal part of the Nordland Group occurring as an infilling unit within the Viking Graben in the Norwegian sector. The sediments are sandy on the East Shetland Platform and in the western and northern parts of the Viking Graben. In the eastern and southern parts and south of the Viking Graben, the deposits are mainly silty and clayey. Sandy Middle Miocene sediments are recorded in wells 25/1-8 S, 25/2-10 S (western Viking Graben), 26/10-1 (southeastern Viking Graben), 9/09a-A 23 (East Shetland Platform, UK sector), 16/3-5 (southern Viking Graben, may be part of an injectite), 15/9-13 (southern Viking Graben) and 30/5-2 and 30/6-3 (170 m thick; northern Viking Graben; Fig. 3; Eidvin et al., 2013; Eidvin, 2016). Especially the Middle Miocene section in well 25/1-8 S was probably deposited at a very shallowmarine site. In the shallow-marine environment it may be difficult to distinguish these sands from sands of the Utsira Formation above and the Skade Formation below, and they are believed to act as one aquifer system (Halland et al., 2011, updated 2019; Eidvin et al., 2013). In spite of being noisy, seismic data show that in the Middle Miocene or possible Lower Miocene, an eastward-prograding delta system was developed in the Frigg area. Wells 25/1-8 S and 9/09a-A 23 penetrated the sandy deposits in the delta plain while well 25/2-10 S was drilled east of the clinoform belt. A thick depocentre of Middle Miocene sands was developed east and north of the Frigg area in a more distal shelf environment (sands penetrated in wells 30/5-2 and 30/6-3; figure 12 in Eidvin et al., 2013). The Middle Miocene sandy sections appear to form mappable units which are clearly younger than the Skade Formation and older than the Utsira Formation in the Viking Graben. Eidvin et al. (2013) tentatively introduced the name Eir formation, after an Æsir (god) in Norse mythology, for these units in the 


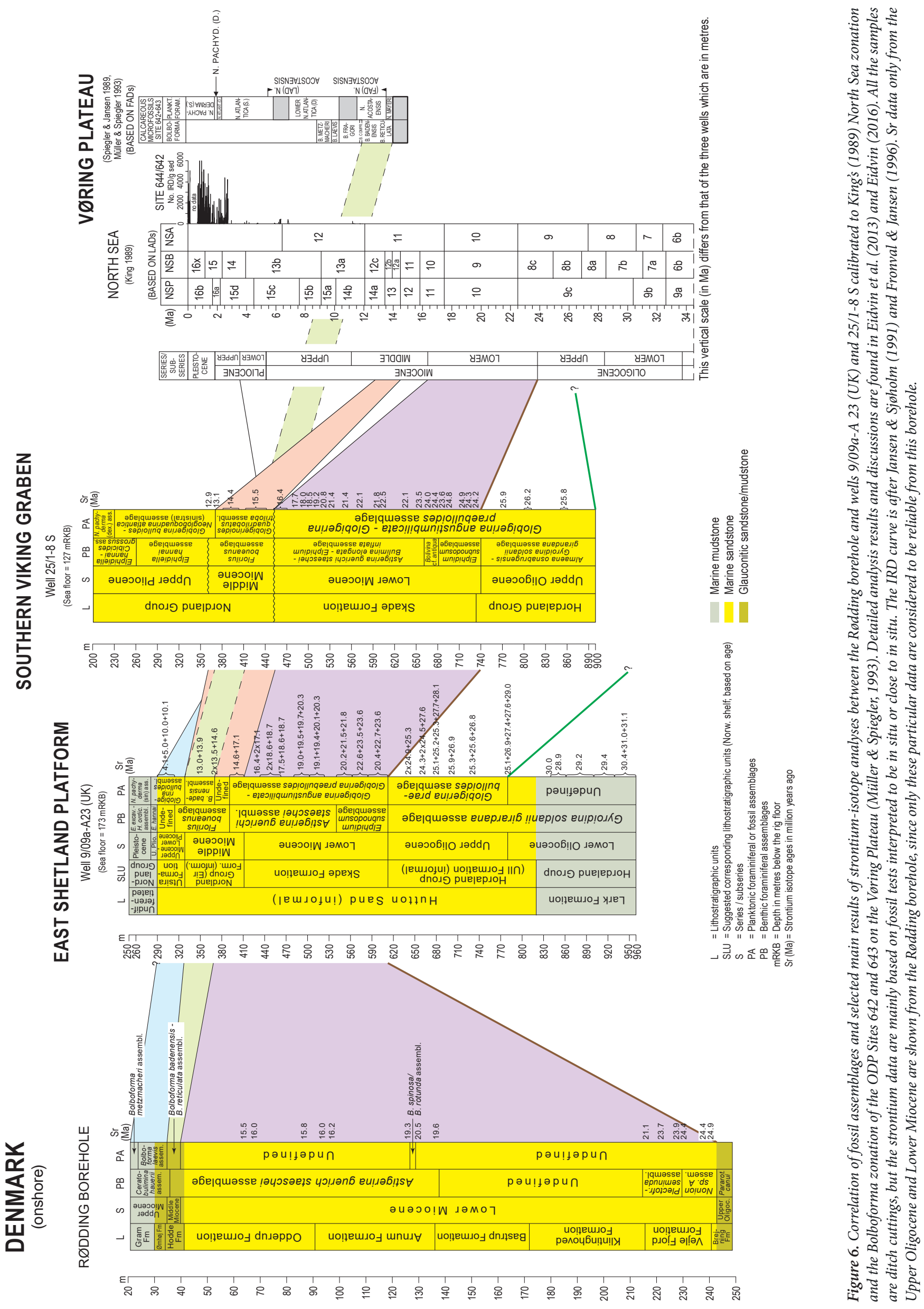


Norwegian sector, representing a new formation in the Nordland Group (Fig. 10).

During the Late Miocene to Early Pliocene, the northern North Sea apparently formed a narrow seaway between the deeper water in the Møre Basin and the central North Sea. The central North Sea received large amounts of coarse sand (Utsira Formation). The Utsira Formation represents a huge sedimentary depositional system in the northern North Sea (about $450 \mathrm{~km}$ long and $90 \mathrm{~km}$ wide; Fig. 3), comprising one large sandy depocentre (250-300 $\mathrm{m}$ in the southern Viking Graben) and an area with 80-100 m-thick sandy deposits in the northern Viking Graben (figure 11 in Eidvin et al., 2013; Halland et al., 2011, updated 2019). The western central area of the Viking Graben comprises a large deltaic system which prograded eastwards in the Early and Middle Miocene. Here, Upper Miocene to Lower Pliocene sediments of the Utsira Formation are thin or absent due to lack of accommodation space (Fig. 10). Numerous wells have penetrated these deposits, and several of these have been investigated for benthic and planktonic foraminifera, Bolboforma and $87 \mathrm{Sr} / 86 \mathrm{Sr}$ ratios (marked with red dots in Fig. 3; Eidvin et al., 2013). Apparently, the progradation of the delta front stopped in the Middle/Late Miocene. The sediments were transported to the delta slope and the shallow shelf beyond the delta, suggesting a relative fall in sea level. In the Tampen area to the north, the Utsira Formation is represented by a thin glauconitic unit dated to the latest Miocene to Early Pliocene. There, it is overlying Oligocene and Lower Miocene deposits. Offshore western Norway, north of the Troll Field a sandy deltaic system developed. This delta was probably fed by the Sognefjorden paleo-valley (Fig. 13). In the western part of the Norwegian sector blocks 30 and 25, the Utsira Formation merges with parts of the Hutton sand (see Fig. 3).

\section{Norwegian Sea shelf}

In the Late Miocene, coastal plains and deltas of the Molo Formation built out along the inner continental shelf of the Norwegian Sea (Eidvin et al., 2013; Grøsfjeld et al., in press and unpublished dinocyst data (personal observations)). In the northern distribution area off Vesterålen, this has been interpreted to be due to a relative sea-level fall probably mainly caused by uplift of the coastal zone/mainland (Grøsfjeld et al., in press). Here, in the northeastern part of the distribution of the Molo Formation (well 6610/3-1), the progradation of coastal sand initiated in the Tortonian (Grøsfjeld et al., in press). In the southern part of its distribution, the Molo Formation (Draugen Field, Trøndelag Platform) contains glauconite sand (Eidvin et al., 2013). On the shelf to the west, clayey and hemipelagic sediments accumulated, whereas on the slope and rise pelagic ooze was deposited (middle/upper part of the Kai Formation).

\section{Material and methods}

\section{Strontium isotope analyses}

Eidvin et al. (2014a) obtained ${ }^{87} \mathrm{Sr} /{ }^{86} \mathrm{Sr}$ ratios of 143 samples from 18 localities from the Upper Oligocene to Upper Miocene Danish succession. Fifty-four of these samples were from the Rødding well (Fig. 1). The analyses were mainly carried out on fragments of mollusc shells, tests of foraminifera and Bolboforma, in addition to one sample representing a shark tooth. The collected shell material was supplemented with mollusc shells picked from the collection of Leif Banke Rasmussen, stored at the Geological Museum in Copenhagen (Rasmussen, 1966). The results were presented in Eidvin et al. (2014a). However, since the strontium isotope data from the Middle-Upper Miocene are uncertain, as mentioned above, only strontium isotope data from the Upper Oligocene-Lower Miocene part (94 samples from 18 localities) have been used for the correlation in the present paper. These are listed in Table 1.

\section{Biostratigraphy}

Micropalaeontological investigations in the Rødding borehole were based on analyses of planktonic and benthic foraminifera and Bolboforma. Pyritised diatoms were also used to establish a stratigraphy for the Upper Oligocene-Lower Miocene part (see Eidvin et al., 2013).

The fossil assemblages are mainly correlated with the micropalaeontological zonation for Cenozoic sediments of King $(1983,1989)$. The zonations based on Bolboforma species (Spiegler \& Müller, 1992; Müller \& Spiegler, 1993; Spiegler, 1999) from ODP and DSDP drillings in the Norwegian Sea and the North Atlantic are very important for dating the Middle-Upper Miocene part of the column. Correlation with these zones yields the most accurate age determinations, because the zones are calibrated with both nannoplankton and palaeomagnetic data.

\section{Correlation}

The strontium isotope analyses of samples from the Danish Brejning, Vejle Fjord, Klintinghoved, Arnum and Odderup formations gave ages between 25.7 (Late Oligocene) and 15.5 Ma (early Middle Miocene; Fig. 2). These sediments, which have also been analysed for foraminifera and pyritised diatoms in the Rødding borehole (Figs. 1 and 3; Eidvin et al., 2013), can be correlated with deposits from a number of lithological units in the Norwegian North Sea and the East Shetland 


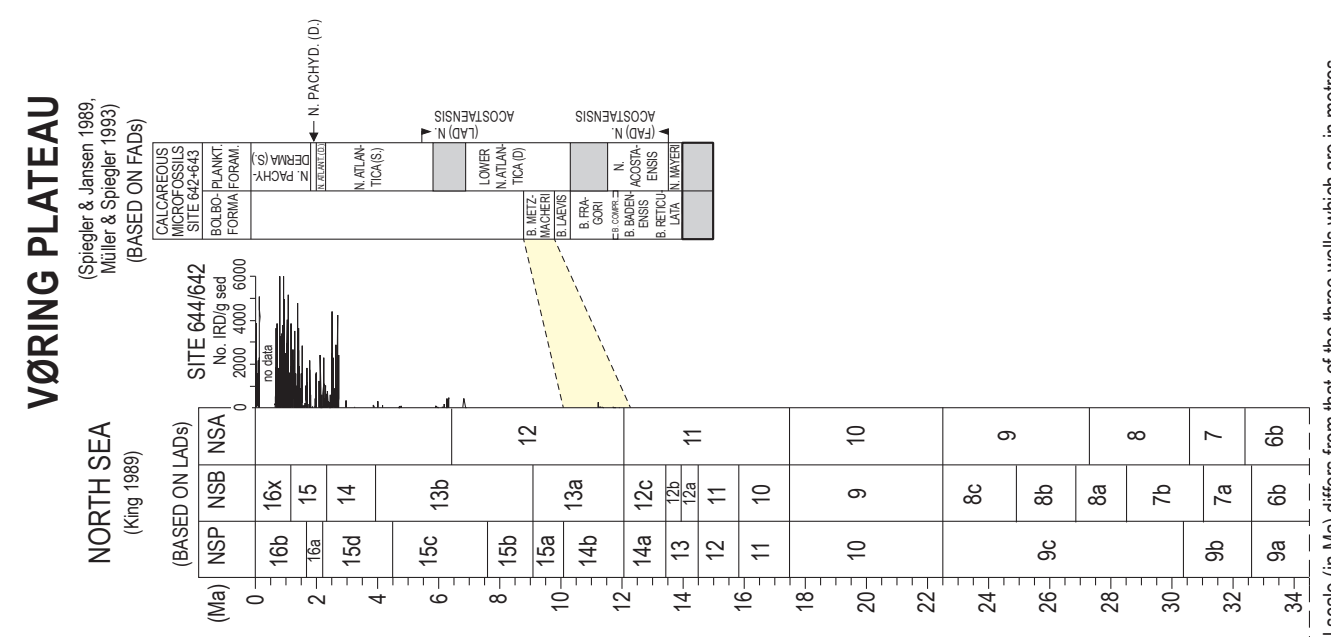

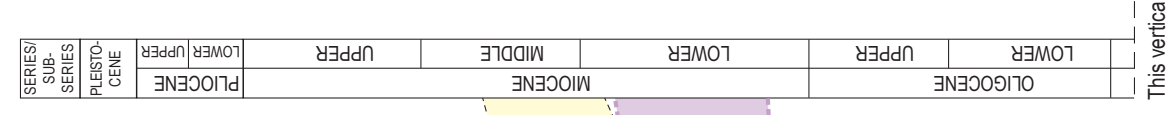
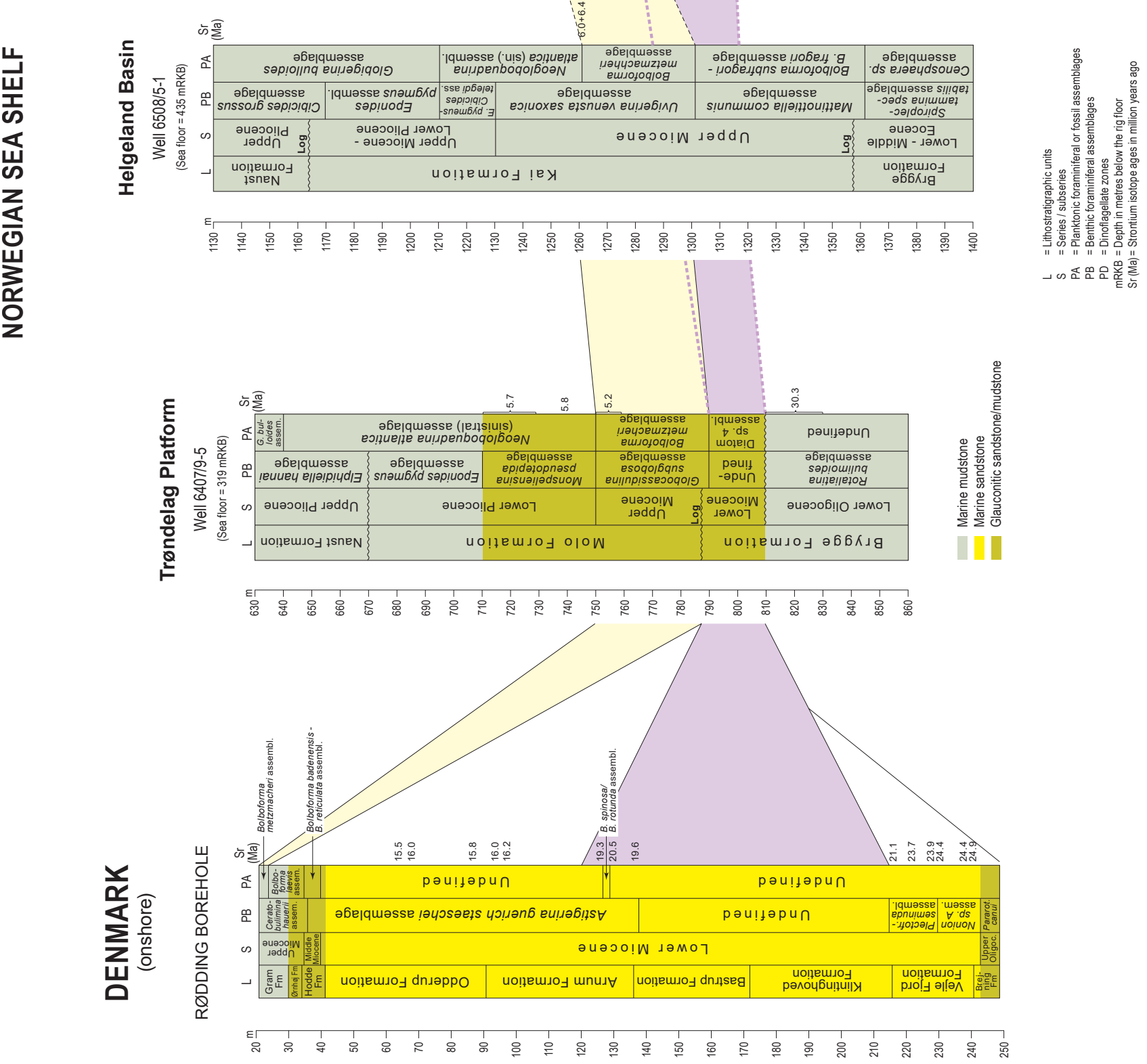
Figure 7. Correlation of Bolboforma between the Rødding borehole and wells 6407/9-5 and 6508/5-1, calibrated to King's (1989) North Sea zonation and the Bolboforma zonation of the ODP Sites 642 and 643 on the Vøring Plateau (Müller \& Spiegler, 1993). Detailed analysis results and discussions are found in Eidvin et al. (2007, 2013). All the samples are ditch cuttings, but the strontium data are mainly based on fossil tests interpreted to be in situ or close to in situ. The IRD curve is after Jansen \& Sjøholm (1991) and Fronval \& Jansen (1996). Sr data only from the Upper Oligocene and Lower Miocene are shown from the Rødding borehole, since only these particular data are considered to be reliable from this borehole.

Platform, which have been investigated applying similar methodology. These include the Hutton sand (informal; East Shetland Platform), clay-rich deposits of the Hordaland Group (central, southeastern and northern North Sea), the sandy Skade Formation (northern North Sea) and the sandy Eir formation (informal; Figs. 10 \& 11). Some of these correlations are visualised in detail (Figs. 4-7).

Figure 4 shows that, based on $\mathrm{Sr}$ isotope and benthic foraminiferal data, the Brejning Formation in the Rødding borehole correlates with the Upper Oligocene part of the Hordaland Group in wells 24/12-1 and 25/10-2 in the southern Viking Graben and King's (1989) NSB Zone 8 from the North Sea. The Vejle Fjord Formation in the Rødding borehole correlates with the Lower Miocene part of the Hordaland Group, below the Skade Formation, in well 24/12-1, the Lower Miocene part of the Hordaland Group, lower part of the Skade Formation in well 25/10-2 and the lower main part of the NSB Zone 9 of King (1989). The Klintinghoved, Bastrup, Arnum and Odderup formations correlate with the main part of the Skade Formation in well 24/12-1 and the upper main part of the Skade Formation in well 25/10-2 and King's (1989) NSB Zone 10 and the upper part of NSB Zone 9.

The correlation of the Hodde, Ørnhøj and Gram formations in the Rødding borehole is based on Bolboforma assemblages. Similar Bolboforma assemblages, in the Hodde and Gram formations, are recorded from the Gram, Lille Tønde and Borg-1 boreholes on the Ringkøbing High and in the North German Basin (southern Jylland) by Laursen \& Kristoffersen (1999, Fig. 8). Figure 4 shows that the Bolboforma badenensis-Bolboforma reticulata assemblage in the Hodde Formation correlates with similar assemblages in the fine-grained lowermost part of the Nordland Group situated between the sandy Skade and Utsira formations in wells 24/12-1 and 25/10-2 (see also Eidvin et al., 2013). These assemblages correlate in turn with the Bolboforma badenensis-Bolboforma reticulata Zone of Müller \& Spiegler (1993) from the Vøring Plateau (Norwegian Sea; Fig. 8), which has been dated accurately to slightly older than 14 to $11.7 \mathrm{Ma}$ (Middle Miocene; Spiegler \& Müller, 1992). Bolboforma of a Bolboforma laevis assemblage and a Bolboforma metzmacheri assemblage are recorded in the Ørnhøj and Gram formations. In well 24/12-1, a Bolboforma fragori assemblage is recorded from the lowermost part of the Utsira Formation. In well 25/10-2 a Bolboforma fragori assemblage and a Bolboforma metzmacheri assemblage are recorded from the lower part of the Utsira Formation (see also Eidvin et al., 2013). These assemblages correlate with a Bolboforma fragori/Bolboforma subfragori Zone (accurately dated to 11.7-10.3 Ma, earliest Late Miocene), Bolboforma laevis Zone (10.3-10.0 Ma, Late Miocene; $B$. laevis is also present in the B. fragori/Bolboforma subfragori Zone) and Bolboforma metzmacheri Zone (10.0-8.7 Ma, Late Miocene) on the Vøring Plateau (Quale \& Spiegler, 1989; Spiegler \& Müller, 1992; Müller \& Spiegler, 1993).

Based on Sr and benthic foraminiferal data, the Brejning Formation in the Rødding borehole correlates with the Upper Oligocene part of the Hordaland group in wells 25/2-10 S and 25/1-8 S in the southern Viking Graben and King's (1989) NSB Zone 8 from the North Sea (Fig. 5). The Vejle Fjord, Klintinghoved and Bastrup formations and the lower part of the Arnum Formation in the Rødding borehole correlate with the Skade Formation in well 25/2-10 S. The Vejle Fjord, Klintinghoved and Bastrup formations and the whole of the Arnum Formation correlate with the Skade Formation in well 25/1-8 S. All of these units correlate in turn with the NSB 9 Zone and NSB 10 Zone of King (1989).

According to Figure 5, the correlation of the Hodde Formation in the Rødding borehole is based mainly on Bolboforma assemblages. The Bolboforma badenensisBolboforma reticulata assemblage correlates with similar assemblages in the sandy lowermost part of the Nordland Group (suggested to be named the Eir formation by Eidvin et al., 2013) situated between the Skade and Utsira formations in wells 25/2-10 S and 25/1-8 S. These assemblages correlate in turn with the Bolboforma badenensis-Bolboforma reticulata Zone of Müller \& Spiegler (1993) from the Vøring Plateau (Norwegian Sea; Fig. 8), dated to slightly older than 14 to $11.7 \mathrm{Ma}$ (Middle Miocene). Sediments with the same age as the Ørnhøj and Gram formations in the Rødding borehole are not present in the wells 25/2-10 S and 25/1-8 S (Fig. 5).

Figure 6 shows that, based mainly on Sr data, the Vejle Fjord, Klintinghoved, Bastrup, Arnum and Odderup formations in the Rødding borehole correlate with the upper main part of the Hutton sand in well 9/09a-A 23.

The Hodde Formation, based on the Bolboforma badenensis-Bolboforma reticulata assemblage in the Rødding borehole, is correlated with a similar assemblage in well 9/09a-A 23. These assemblages correlate again with the Bolboforma badenensis-Bolboforma reticulata Zone of Müller \& Spiegler (1993) from the Vøring Plateau (Norwegian Sea; Fig. 8) which, as noted above, 
has been dated accurately to slightly older than 14 to 11.7 Ma (Middle Miocene; Spiegler \& Müller, 1992). The Ørnhøj and Gram formations in the Rødding borehole are tentatively correlated with the uppermost part of the Hutton sand in well 9/09a-A 23.

Figure 6 also shows that, based on $\mathrm{Sr}$ and benthic foraminiferal data, most of the lower part of the Hutton sand in well 9/09a-A 23 correlates with the Hordaland Group in well 25/1-8 S and King's (1989) NSB Zone 8 from the North Sea. Based on the same kind of data, the middle part of the Hutton sand in well 9/09a-A 23 correlates with the Skade Formation in well 25/1-8 S and the NSB 9 Zone and NSB 10 Zone of King (1989). Based on $\mathrm{Sr}$ and benthic foraminiferal data, Figure 6 also shows that the Middle Miocene part of the Hutton sand in well 9/09a-A 23 correlates with the lower part of the Nordland Group in well 25/1-8 S. Sediments with a similar age as the uppermost part of the Hutton sand in well 9/09a-A 23 are not present in well 25/1-8 S.

Figure 7 shows that, based on $\mathrm{Sr}$ and pyritised diatoms (Diatom sp. 4 assemblage), the Klintinghoved and Bastrup formations and lower part of the Arnum Formation in the Rødding borehole correlate with the upper part of the Brygge Formation in well 6407/9-5 (Trøndelag Platform) and Zone NSP 10 of King (1989) from the North Sea. This correlation is verified by unpublished dinocyst data (personal observations). The upper part of the Gram Formation in the Rødding borehole is of a similar age as the lower part of the Molo Formation in well $6407 / 9-5$ and the middle part of the Kai Formation in well 6508/5-1 (Helgeland Basin; see Fig. 14), which again correlates with the Bolboforma metzmacheri Zone (10.0-8.7 Ma, Late Miocene) on the Vøring Plateau (Spiegler \& Müller, 1992; Müller \& Spiegler, 1993; also verified by unpublished dinocyst data (personal observations)).

\section{Discussion}

The idealised palaeogeography for the Middle-Late Miocene advocated by Løseth \& Henriksen (2005) shows a situation with a large land area stretching from presentday Shetland Island to southern Norway (their figure 15). Our divergent views on the geological history have led to a discussion in geoscience journals including the following articles: Eidvin et al. (2013, 2014b), Løseth et al. (2013), Rundberg \& Eidvin (2016ab), Løseth et al. (2016b), Løseth \& Øygarden (2016), Eidvin \& Rundberg (2016a, b) and Løseth (2016). In the present paper we want to document and elaborate our view more thoroughly.

According to several authors, including Knox et al. (2010) and Rasmussen et al. (2008), during the Miocene the North Sea was not in contact with an open ocean towards the east, west and south (Fig. 8). According to Løseth \& Henriksen (2005) and Løseth et al. (2013) a compressional phase and related major regression would have led to an isolation of the North Sea Basin. This compressional phase is shown as terminating approximately at the top Miocene (their figure 17). This partly reflects their estimate of the age of the Utsira Formation to the Early Pliocene. An opening to the south, in addition an opening to the north, formed first as late as in the late Pleistocene when repetitive mega-floodings, caused by breaching of rock dams at the Dover Strait, instigated catastrophic drainages of large pro-glacial lakes in the southern North Sea Basin. Two periods with catastrophic floods, after 450,000 but before 180,000 years ago, formed bedrock-floored valleys. Thus, Britain was isolated from continental Europe during high sealevel stands during the Eemian and Holocene (Sanjeev et al., 2007; Gibbard, 2007, Gibbard \& Cohen, 2015).

A major sea-level fall within the Late Miocene is indicated by a number of features, including deep channelling beneath the Tortonian Deurne Member in Belgium (Houthuys, 2014; Vandenberghe, 2014), incision of Upper Miocene delta systems within the central North Sea (Møller et al., 2009) and the rapid progradation of the Eridanos Delta into the central North Sea Basin (Overeem et al., 2014; Kuhlmann et al., 2006; Patruno et al., 2019). However, there are no stratigraphic or sedimentological data suggesting a closure of the basin. The incision of the pre-Deurne Member channels implies strong tidal currents, which are unlikely to have been generated in a closed sea. In addition, in the thick and apparently continuous Upper Miocene succession in the central North Sea there are no signs of stratification, reduced salinity or lowered oxygenation which can be deduced from the sediments or the microfauna. The key evidence is provided by the plankton. Several Bolboforma zones, described from and accurately dated in scientific boreholes from the Norwegian Sea and North Atlantic, up to and including the B. metzmacheri Zone (c. 10.0-8.7 Ma, through the Serravallian to mid Tortonian; Spiegler \& Müller, 1992; Müller \& Spiegler, 1993), are represented in the central North Sea Basin, onshore southern Denmark and in other onshore areas (King, 1989; Laursen \& Kristoffersen, 1999; Eidvin \& Rundberg, 2007; Eidvin et al., 2013), indicating the existence of an open connection to the North Atlantic/ Nordic seas throughout this period. The succeeding B. intermedia Zone (c. 8.8-5.9 Ma: late Tortonian and Messinian; Spiegler \& Müller, 1992) is also identified (though rarely) in both onshore and offshore areas (Chris King, personal communication). Planktonic foraminifera are represented throughout almost all this interval in some areas. A succession of pteropod zones is identified through the early Tortonian (Gürs \& Jansen, 2002). Planktonic foraminifera are represented (quite commonly) through the Upper Miocene in the central North Sea Basin (e.g., well 2/4-C-11 (Eidvin et 


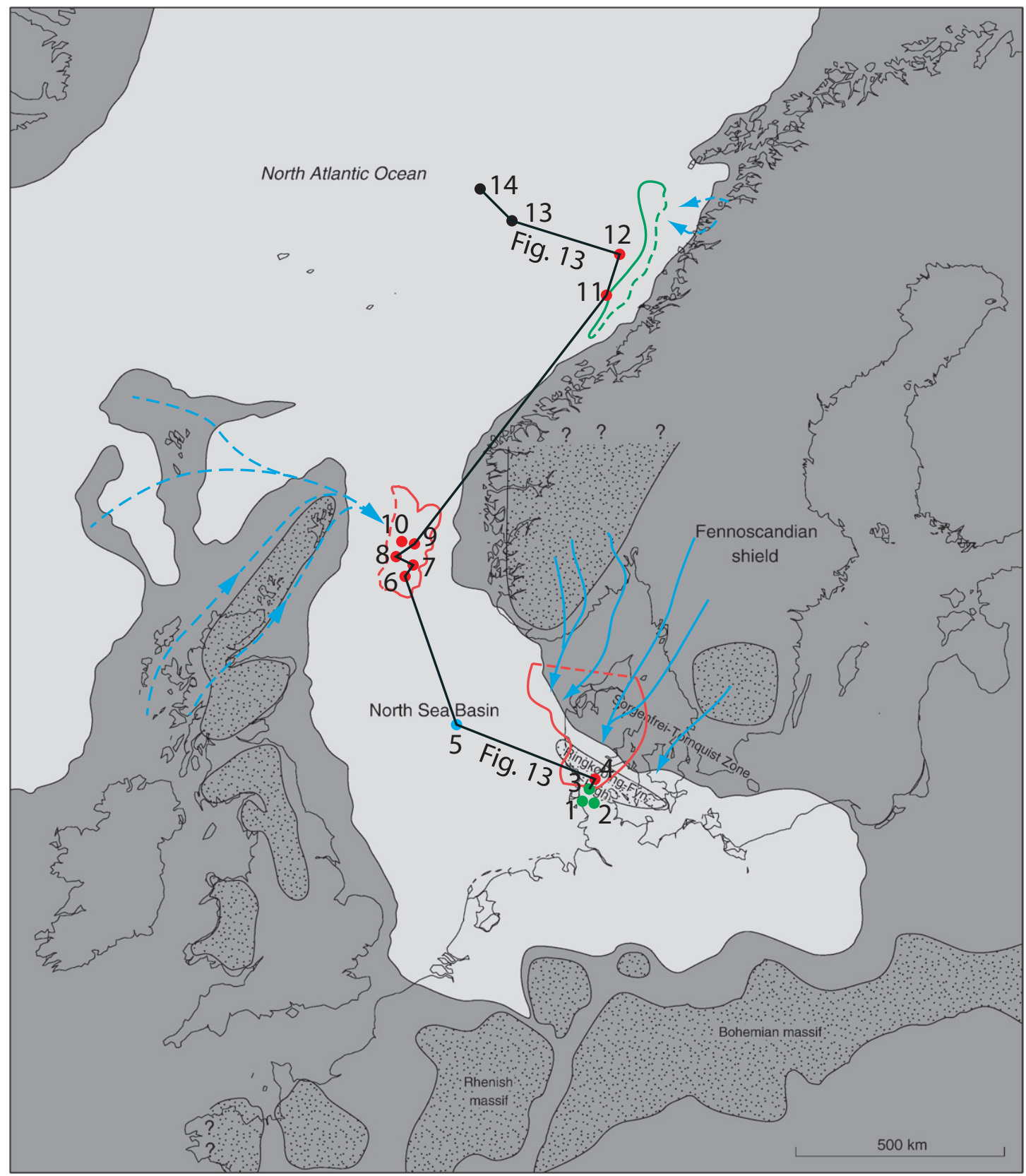

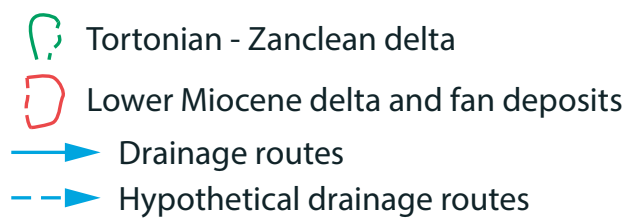

- Wells and boreholes shown in the correlation diagrams (Figs. 4-7)

- Scientific deep-sea boreholes

- Boreholes investigated by Laursen and Kristoffersen (1999)

- Well investigated by Eidvin et al. $(1999,2013)$
1: Lille Tønde borehole
2: Borg-1 borehole
3: Gram borehole
4: Rødding borehole
5: Well 2/4-C-11
6: Well 24/12-1
7: Well 25/10-2
8: Well 9/09a-A 23 (UK)
9: Well 25/2-10 S
10: Well 25/1-8 S
11: Well 6407/9-5
12: Well 6508/5-1
13: ODP Site 644
14: ODP Site 642

Figure 8. Palaeogeographic reconstruction of the North Sea Basin and adjacent areas in the Miocene (after Knox et al., 2010; Rasmussen et al., 2008; Dybkjor \& Piasecki, 2010). The extents of the Miocene deltas and fan deposits and possible drainage routes in Denmark are from figure 3. Hypothetical drainage routes for the Hutton sand and Skade Formation are modified from Halland et al. (2014) and Gjeldvik et al., (2011). The approximate positions of the wells and boreholes from the correlation diagrams in Figures 4-7 are indicated with red dots and numbers. Other wells and boreholes are indicated with black, green and blue dots. 


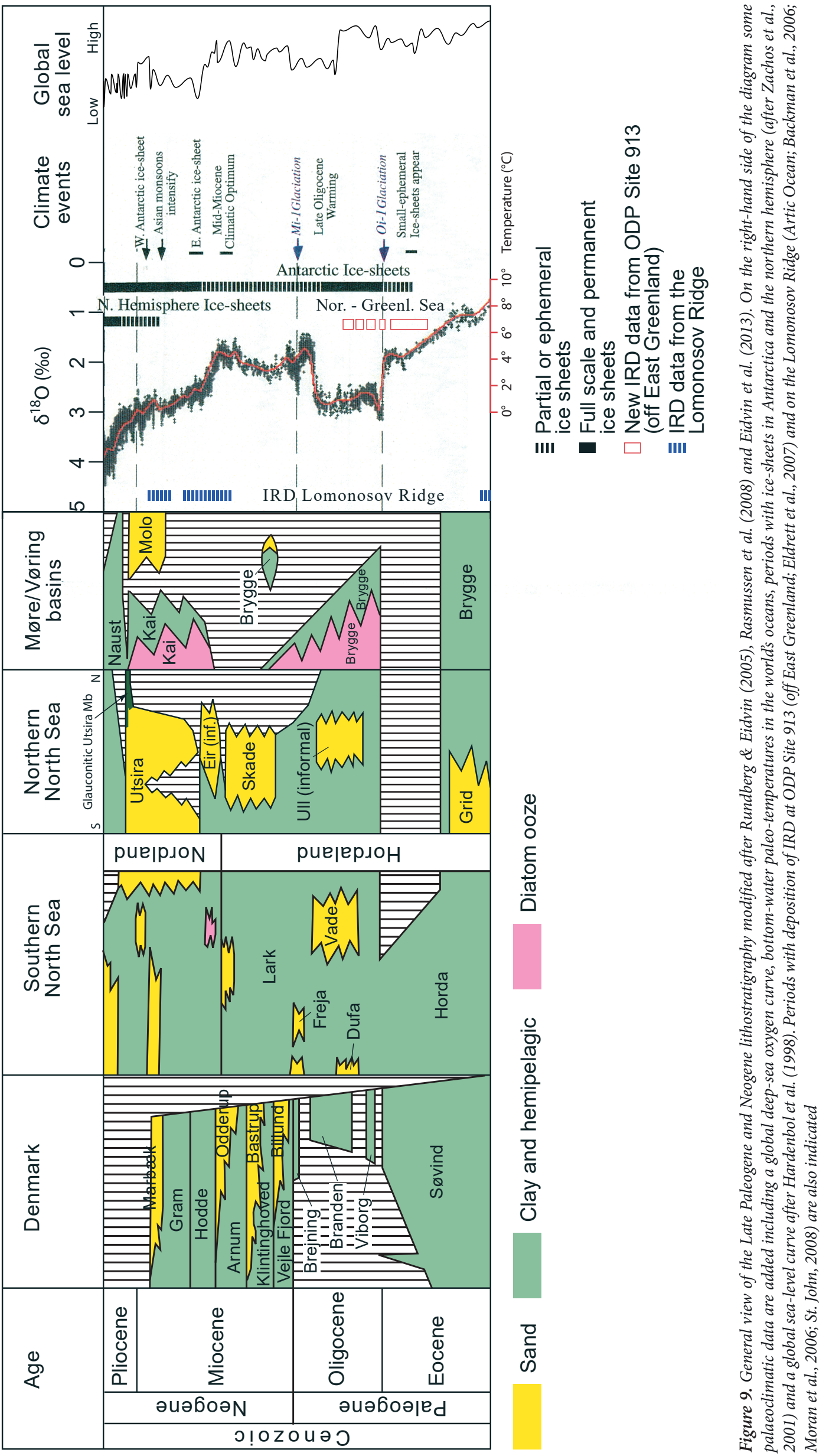




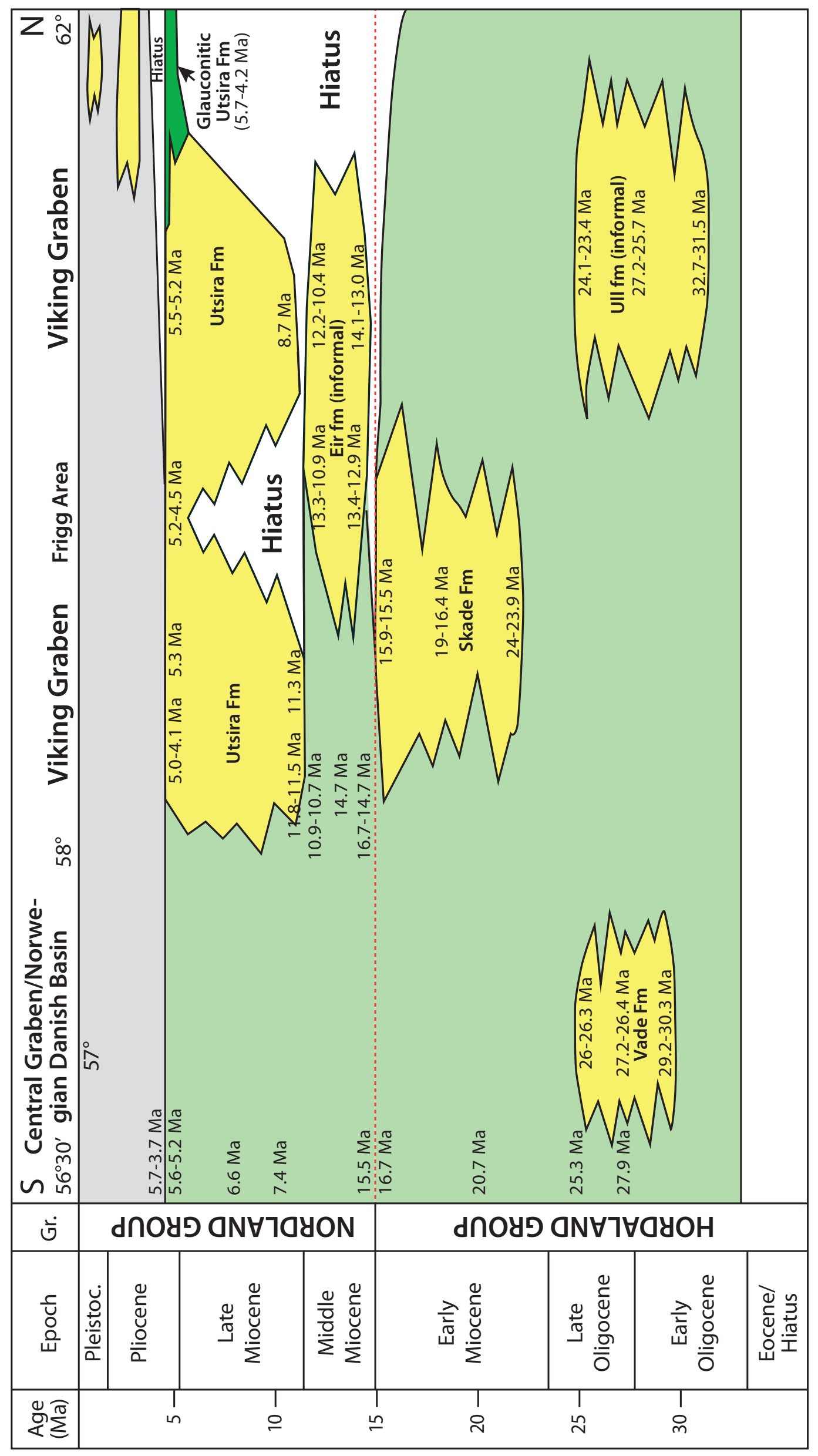




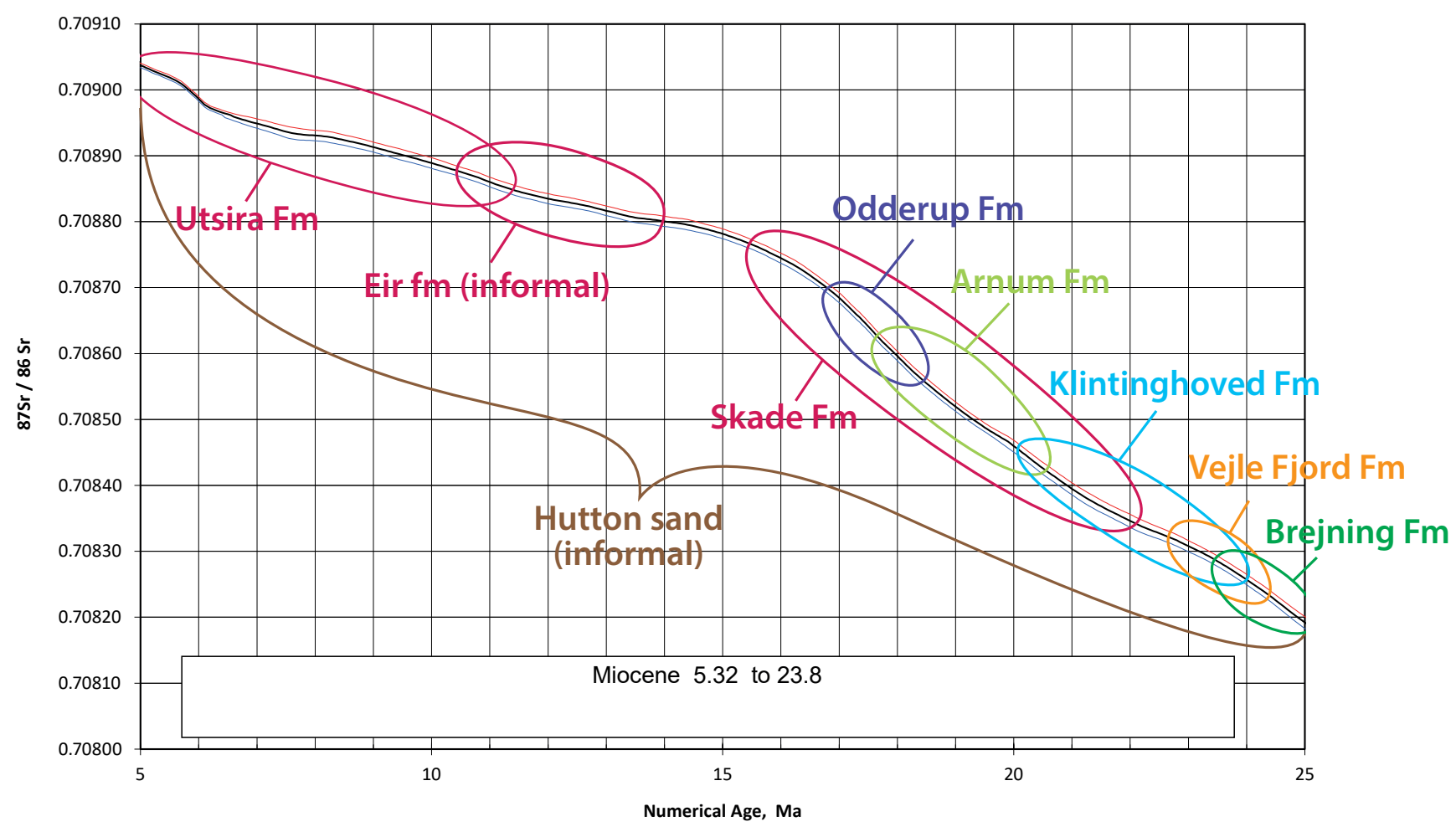

Figure 11. Curve showing strontium-isotope evolution of seawater from 25 to $5 \mathrm{Ma}$ (from Howarth \& McArthur, 1997). For clairity, the obtained ${ }^{87} \mathrm{Sr}{ }^{86} \mathrm{Sr}$ ratios (y-axis) and corresponding ages ( $x$-axis; mean values) for the Norwegian Skade, Eir (informal) and Utsira formations, the Danish Brejning, Vejle Fjord, Klintinghoved, Arnum and Odderup formations and the British Hutton sand (informal; from Figs. 2, 6 \& 10) are indicated with different colours.

al., 1999, 2013)). The late Tortonian (7.5 Ma) transition from dextral to sinistral Neogloboquadrina atlantica is also identified in the central North Sea (Spiegler \& Jansen, 1989; King, 1989). Dinocyst assemblages also indicate continuing oceanic connections, and there is no stratigraphical break in the Miocene-Pliocene succession in Denmark (Dybkjær \& Piasecki, 2010).

In the correlation chapter and Figures 4-7 we described the correlations of Bolboforma assemblages from the Ringkøbing-Fyn High, in the southeast, through the Central and Viking grabens to the Norwegian Sea shelf and Vøring Plateau (Norwegian Sea) in the north (see Fig. 8).

Figure 14 synthesises the Bolboforma correlation. The Bolboforma badenensis-Bolboforma reticulata assemblage, the oldest assemblage, is recorded from the Hodde Formation in the Gram-1 borehole (Laursen \& Kristoffersen, 1999) and the Rødding borehole (both from the Ringkøbing-Fyn High). Laursen \& Kristoffersen (1999) also recorded this assemblage farther south from the Borg-1 and Lille Tønde boreholes in the North German Basin (Fig. 8; not included in Fig. 14). The assemblage is not recorded in well 2/4-C-11 (Central Graben) since there is a local hiatus in the Middle Miocene in that area, possibly due to salt tectonics and polygonal faulting (Eidvin et al., 2013). In the Viking Graben, the $B$. badenensis- $B$. reticulata assemblage is recorded from the Nordland Group, including the lowermost part of the Utsira Formation, in wells 24/12-1 and 25/10-2 as well as in the Nordland Group in well 25/2-10 S. The lack of the top of the assemblage in the latter well is probably due to a break in the stratigraphy. Towards the west, the $B$. badenensis- $B$. reticulata assemblage is recorded in the UK well 9/09a-A 23 on the East Shetland Platform. As seen in Figure 14, in the scientific boreholes at ODP Sites 642 and 644 on the Vøring Plateau the occurrence of B. badenensis and $B$. reticulata is estimated to be slightly older than 14 to c. 11.7 Ma (Middle Miocene; Spiegler \& Müller, 1992; Müller \& Spiegler, 1993).

Higher up in the sections at ODP Sites 642 and 644, Spiegler \& Müller (1992) and Müller \& Spiegler (1993) described a B. fragori/B. subfragori Zone from sediments with an age of approximately $11.7-10.3 \mathrm{Ma}$ (earliest Late Miocene). Between the B. badenensis-B. reticulata Zone and the $B$. fragori/B. subfragori Zone they described a very thin Bolboforma compressispinosa Zone. Immediately above the B. fragori/B. subfragori Zone, Spiegler \& Müller (1992) and Müller \& Spiegler (1993) described a Bolboforma laevis Zone extending up to sediments estimated to c. $10 \mathrm{Ma}$ in age. B. laevis and $B$. clodiusi are also common in the B. fragori/B. subfragori Zone (Quale \& Spiegler, 1989; Müller \& Spiegler, 1993).

Laursen \& Kristoffersen (1999) recorded B. clodiusi assemblages from the Gram Formation in the Borg-1 and Lille Tønde boreholes (North German Basin) and the Gram-1 borehole (Ringkøbing-Fyn High; Fig. 8). Eidvin et al. (2013) recorded a B. laevis assemblage from the 


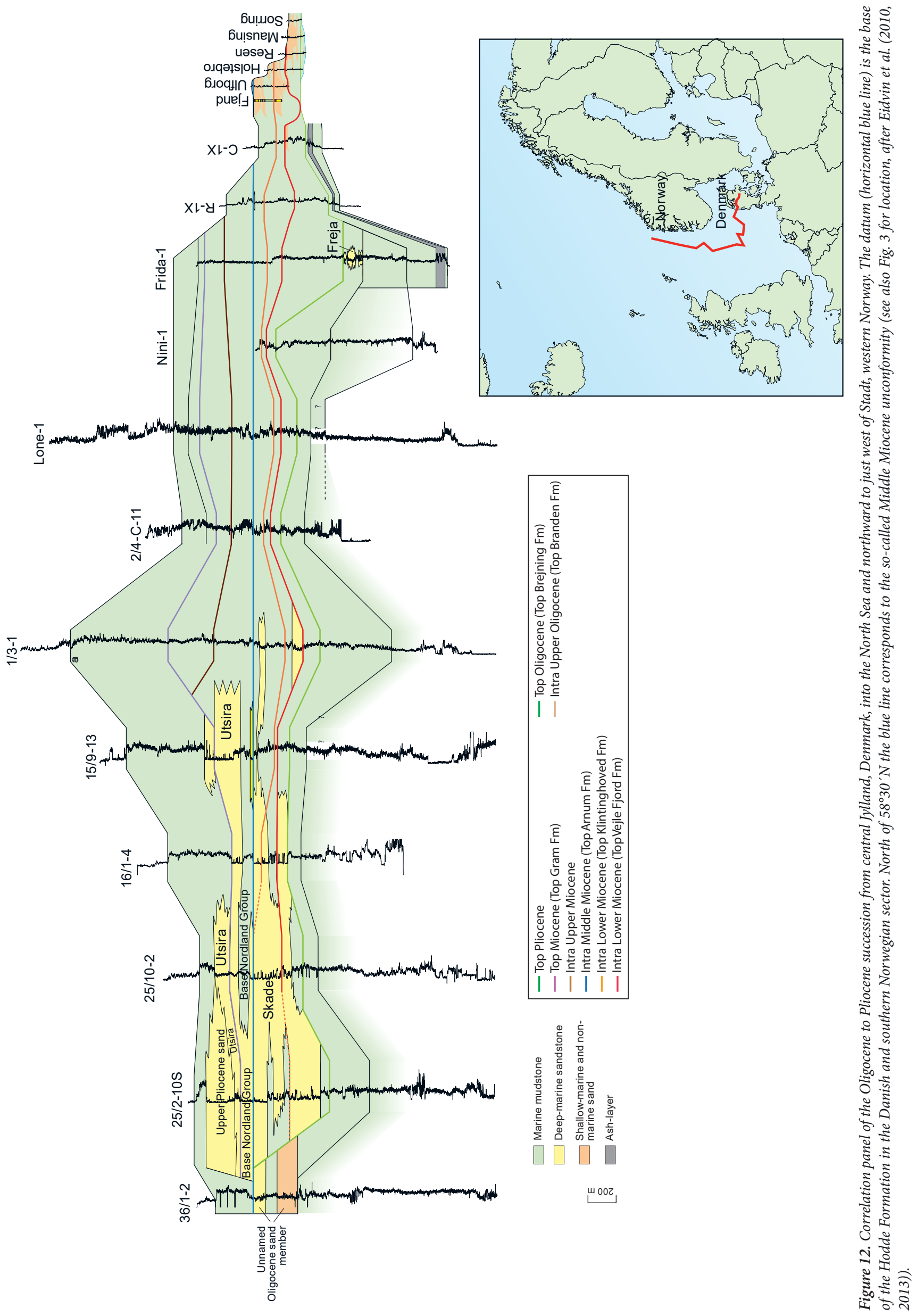




\section{Northern Viking Graben $-61^{\circ} \mathrm{N}$}

\section{Line NVGTI-92-105}

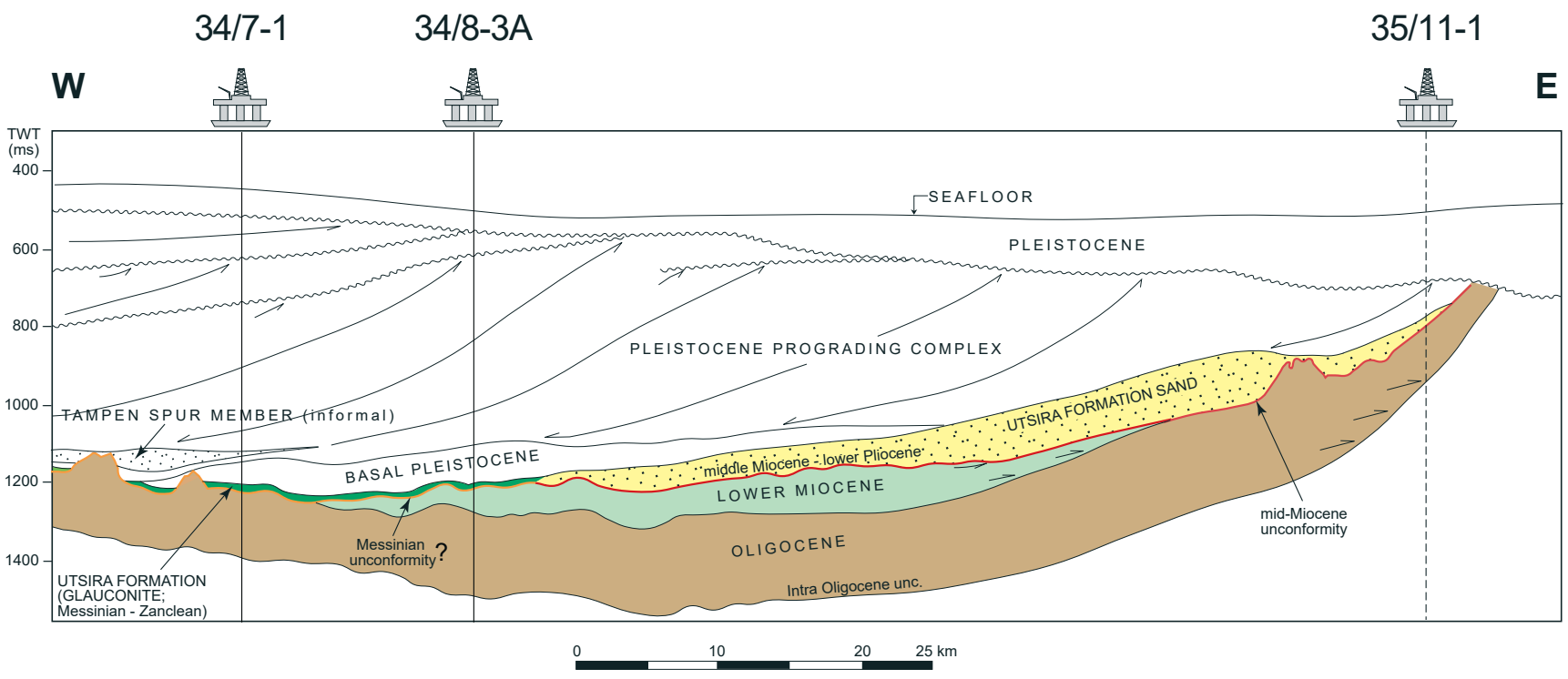

Figure 13. East-west transect of the northern North Sea at about $61^{\circ} \mathrm{N}$ illustrating the main sequences and sedimentary architecture of the post-Eocene strata (see Fig. 3 for location; modified after Eidvin \& Rundberg, 2001, Rundberg \& Eidvin, 2005 and Eidvin et al., 2013).

Ørnhøj and Gram formations in the Rødding borehole (Ringkøbing-Fyn High; Fig. 14). A B. fragori-B. subfragori assemblage is recorded from the Nordland Group in well 2/4-C-11 (Central Graben). B. fragori assemblages are recorded from the Utsira Formation in the wells 24/12-1 and 25/10-2 (Viking Graben; Fig. 14). In well 25/2-10 S (Viking Graben), sediments with a similar age as the $B$. fragori assemblage are eroded.

Above the B. laevis Zone in the boreholes at ODP Sites 642 and 644, Spiegler \& Müller (1992) and Müller \& Spiegler (1993) described a B. metzmacheri Zone from sediments with an age of c. 10-8.7 Ma (Late Miocene). B. metzmacheri assemblages are recorded in the Gram Formation from the Borg-1 and Lille Tønde boreholes (North German Basin; Laursen \& Kristoffersen, 1999), from the Gram-1 and Rødding boreholes (RingkøbingFyn High), from the Nordland Group in well 2/4-C-11 (Central Graben), from the Utsira Formation in well 25/10-2 (Viking Graben), from the lower part of the Molo Formation in well 6407/9-5 (Trøndelag Platform) and from the middle part of the Kai Formation in well 6508/5-1 (Helgeland Basin; Figs. 8 \& 14).

Planktonic foraminifera of Late Miocene age (Spiegler \& Jansen, 1989; Figs. 4-7), as sinistral and dextral coiled N. atlantica, Globigerina bulloides and Globorotalia puncticulata, occur in the upper part of the Utsira Formation in the wells we have investigated in the Viking Graben and in the Nordland Group in the Central Graben (Eidvin et al., 2013).
All these observations clearly show that planktonic deep-sea forms, which have their origin in the North Atlantic and the Norwegian Sea, have been brought by ocean currents through an open strait into the northern and central North Sea during the entire Serravallian, Tortonian, Messinian and Zanclean time interval (approximately 14.5-3.5 Ma).

Deposited in a shelf setting, the sandy Utsira Formation (about 12.5-3.5 Ma; Eidvin et al., 2013) overlies Middle Miocene shales (about 15-12.5 Ma; Eidvin et al., 2013) in a large area in the Norwegian sector of the North Sea. The Utsira Formation thins and appears to be condensed towards the west, shaling out towards the south, east and north. It appears to consist of a lower unit (approximately 12.5-6 Ma), which is mainly restricted to the depo-centres and being commonly strongly affected by soft-sediment deformation, and an upper unit (approximately 5-3.5 Ma) which is less deformed and has a wider distribution (Riis \& Eidvin, $2015,2016)$. In the northernmost part of the Norwegian North Sea (Tampen area) there is a 10-50 m-thick sheet of glauconite sand (approximately 5.7-4.2 Ma; Fig. 15; Eidvin \& Rundberg, 2001; Eidvin, 2009; Eidvin \& Øverland, 2009; Eidvin et al., 2013). The glauconite sand overlies an erosional unconformity. Løseth \& Henriksen (2005) suggested that the erosion was related to Middle Miocene uplift and they correlated it to the uplift of southern Scandinavia. Our alternative interpretation is that there was Early-Middle Miocene uplift along the margin of the Møre Basin which created a submarine 


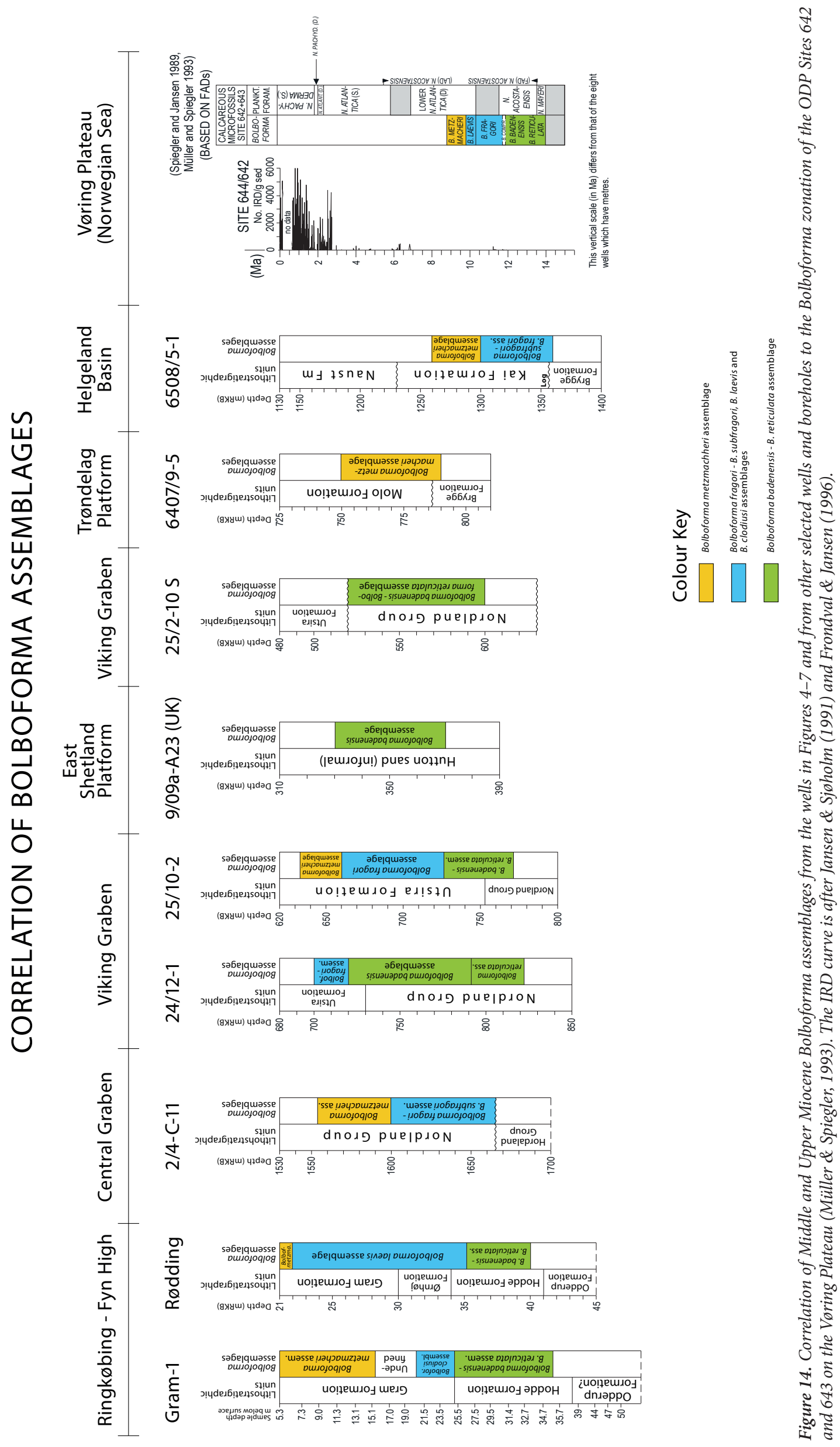




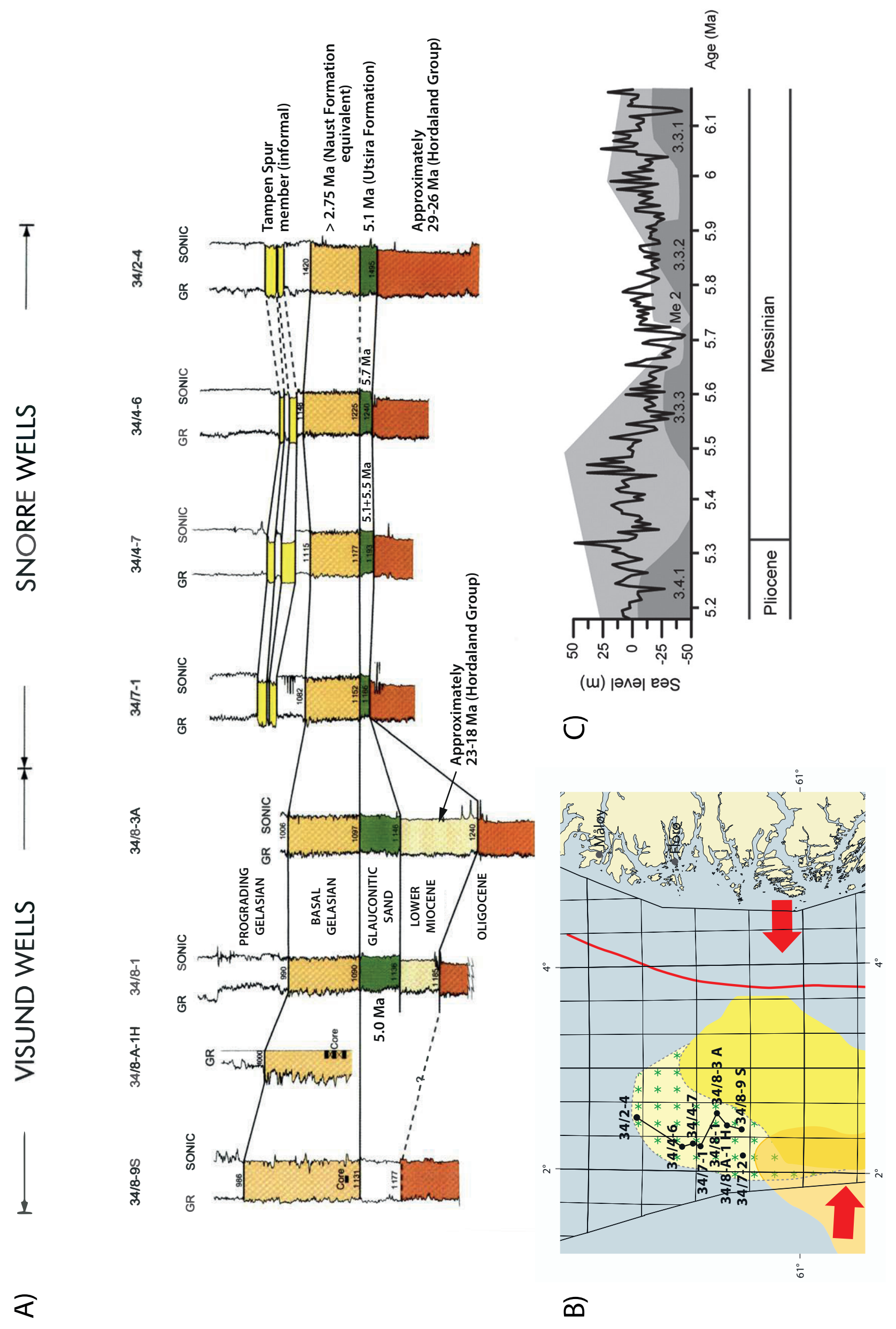


Figure 15. (A) Log correlation diagram of wells from the Visund area (block 34/8), wells from the Snorre area (blocks 34/4 and 34/7) and well 34/2-4 on the northern Tampen Spur (northernmost North Sea; modified after Eidvin \& Rundberg, 2001). (B) Distribution of Utsira Formation sands in the Snorre and Visund Field areas at Tampen. Light and dark yellow areas show the outlines of the main Utsira quartzose sands. Hatched area (with green stars) shows the assumed outline of the thin glauconitic member extending beyond the main Utsira sand. Red lines indicate top Oligocene truncation, whereas red arrows show sediment transport directions (note also well 34/7-2 in the Tordis Field area; modified after Eidvin \& Rundberg, 2001; Rundberg \& Eidvin, 2005). (C) Global sea-level curves of Hardenbol et al. (1998; light-grey shading) and Miller et al. (2005; black line), as well as the 4th-order eustatic cycles of Esteban et al. (1996; darkgrey shading; modified after Pérez-Asensio, 2013). Please note that the glauconitic Utsira Formation sand was deposited coevally with the period of transgression after the Messinian lowstand.

topographic high where probably only small amounts of Miocene sediments accumulated. The erosion that gave rise to the unconformity could have been mainly related to a sea-level drop in the Late Miocene, concurrent with the Messinian salinity crises (Fig. 15). This interpretation is consistent with our view that there was an open seaway in the North Sea throughout the Middle Miocene. It is noted that the unconformity itself is affected by softsediment deformation. The pre-deformational tectonic structure is not easy to reconstruct in the seismic data.

Based on the marine palynomorphs in two ditchcutting samples at 1190 and $1180 \mathrm{~m}$ in well 34/4-6 in the glauconitic Utsira Formation, De Schepper \& Mangerud (2017) assigned a maximum age of 3.0 Ma for the upper part of this formation and a minimum age of 4.6 Ma for the lowermost part. However, as the sediments represent ditch-cutting samples and it was difficult to differentiate between reworked, in situ and caved specimens, they considered this age to be uncertain.

Strontium-isotope ages based on tests of foraminifera which have their last occurrence in the Late Miocene to Early Pliocene in the North Sea (King, 1989), picked from ditch-cutting samples and a sidewall core in wells from the Snorre and Visund fields, gave ages of 5.7-5.2 Ma. Records from a sidewall core from the Tordis Field gave ages of 4.7 and 4.2 Ma (Fig. 15). These ages are substantiated by the fact that glauconite was precipitated, most commonly, during periods with transgression on outer shelves at 200-300 metres water depths (Odin \& Matter, 1981 and Van Houten \& Purucker, 1984). According to Hardenbol et al. (1998) a global transgression started in the middle of the Messinian and a regression in the middle Zanclean.

According to Løseth \& Henriksen (2005) and Løseth et al. (2016a. 2017), the Molo Formation postdates the Kai Formation. The occurrences of the Bolboforma metzmacheri assemblage in the lower part of the Molo Formation in well $6407 / 9-5$, in the middle part of the
Kai Formation in well 6508/5-1 (Fig. 14), in the lower middle part of the Kai Formation in well 6607/5-1 and in the middle to upper part of the Kai Formation in well 6609/5-1 (Eidvin et al., 2013 and unpublished data) suggest that the Molo Formation, in its southern distribution area, correlates with the middle/upper part of the Kai Formation.

\section{Conclusions}

Strontium-isotope data $\left({ }^{87} \mathrm{Sr} /{ }^{86} \mathrm{Sr}\right.$ ratios) from the Upper Oligocene-Lower Miocene succession in Jylland, Denmark (94 samples from 18 localities; Eidvin et al., 2014a), were utilised for correlation with Norwegian wells and boreholes (Eidvin, 2016 and Eidvin et al., 2013, 2014b) together with foraminiferal and pyritised diatom data. Dinocyst correlation is also used in some areas. For the Middle-Upper Miocene parts of the succession the correlations are based mainly on Bolboforma data from a stratigraphic borehole at Rødding in southern Jylland.

The Sr isotope investigations of samples from the Danish, Brejning, Vejle Fjord, Klintinghoved, Arnum and Odderup formations gave ages between 25.7 and 15.5 Ma. These sediments can be correlated with deposits from a number of sedimentological units in the Norwegian North Sea, Norwegian Sea shelf and one well on the East Shetland Platform in UK waters. These include clay-rich deposits of the Hordaland Group (central, southeastern and northern North Sea), Hutton sand (informal; East Shetland Platform), the sandy Skade Formation (northern North Sea) and the Brygge Formation (Norwegian Sea shelf). A Bolboforma assemblage in the Hodde Formation in the Rødding borehole was correlated with sandy and fine-grained deposits in the lower part of the Nordland Group, situated between the Skade and Utsira formations, in the Viking Graben and the upper part of the Hutton sand (informal) on the East Shetland Platform. Bolboforma assemblages in the Ørnhøj and Gram formations in the Rødding borehole were correlated with the lower part of the sandy Utsira Formation (northern North Sea), the lower part of the Molo Formation (in its southern distribution area), middle/upper part of the Kai Formation (Norwegian Sea shelf) and with the ODP boreholes on the Vøring Plateau (Norwegian Sea; Figs. $2,4-7,10,11 \& 14)$. This demonstrates that there must have existed a seaway between the North Sea and the Norwegian Sea during the Middle, Late Miocene and Early Pliocene.

Acknowledgements. The authors are especially grateful to the late Chris King for very important discussions. Many thanks also to Rune Goa (NPD) for drawing most of the figures, Tone Tjelta Hansen (NPD) for technical assistance, Stephan Piasecki (Natural History Museum 
of Denmark) for collecting molluscs, David Roberts (Geological Survey of Norway, NGU) for improving the language, Yuval Ronen (University of Bergen) for executing the strontium isotope analyses and Robert Williams (NPD) for discussions. We acknowledge Morten Smelror (NGU) and Roel Verreussel (TNO Geological Survey of the Netherlands) for their constructive review and NPD, GEUS and the Natural History Museum of Denmark for permission to publish this manuscript.

\section{References}

Backman, J., Moran, K., McInroy, D.B., Mayer, L. \& Expedition 302 Scientists 2006: Proceedings Integrated Ocean Drilling Program 302.

Berggren, W.A., Kent, D.V, Swisher, C.C., III \& Aubry, M.P. 1995: A Revised Cenozoic Geochronology and Chronostratigraphy. In Berggren, W.A. (ed.): Geochronology Time Scale and Global Stratigraphic Correlation, Society for Sedimentary Geology Special Publication 54, pp. 129-212.

https://doi.org/10.2110/pec.95.04.0129.

Berthelsen, A. 1992: Mobil Europe. In Blundell, D.J., Mueller, S. \& Freeman, R. (eds.): A continent revealed: The European Geotraverse Project, Cambridge University Press, pp. 153-164.

Blystad, P., Brekke, H., Færseth, R.B., Larsen, B.T., Skogseid, J. \& Tørudbakken, B. 1995: Structural elements of the Norwegian continental shelf, Part II: The Norwegian Sea Region. Norwegian Petroleum Directorate Bulletin 8, 1-45.

http://www.npd.no/Publikasjoner/NPD-bulletin/258-Bulletin-8/ Geologiske-profiler-og-kart/.

Brekke, H. 2000: The tectonic evolution of the Norwegian Sea Continental Margin with emphasis on the Vøring and Møre Basins. In Nøttvedt, A. et al. (eds.): Dynamics of the Norwegian Margin, Geological Society of London, Special Publications, 167, pp. 327378. https://doi.org/10.1144/GSL.SP.2000.167.01.13.

British Geological Survey, 2000: Saline Aquifer $\mathrm{CO}_{2}$ Storage (SACS), Final Report: Work Area 1 (Geology). BGS commissioned report CR/01/11, 25 pp.

http://www.sintef.no/project/IK23430000\%20SACS/Formal\%20 Reports/SACS2_WA1_Rep_Dec00.pdf.

Bullimore, S., Henriksen, S., Liestøl, F.M. \& Helland-Hansen, W. 2005: Clinoform stacking patterns, shelf-edge trajectories and facies associations in Tertiary coastal deltas, offshore Norway: Implications for the prediction of lithology in prograding systems. Norwegian Journal of Geology 85, 169-187.

Cohen, K.M., Finney, S.C., Gibbard, P.L. \& Fan, J.X. 2013 (updated 2018): The ICS International Chronostratigraphic Chart. Episodes 36: 199-204. https://doi.org/10.18814/epiiugs/2013/v36i3/002.

Denk, T., Grimson, F. \& Kvacek, Z. 2005: The Miocene floras of Iceland and their significance for late Cainozoic North Atlantic biogeography. Botanical Journal 149, 369-417.

https://doi.org/10.1111/j.1095-8339.2005.00441.x.

De Schepper, S. \& Mangerud, G. 2017: Age and palaeoenvironment of the Utsira Formation in the northern North Sea based on marine palynology. Norwegian Journal of Geology 97, 305-325. https://doi.org/10.17850/njg97-4-04.

Dybkjær, K. \& Piasecki, S. 2010: Neogene dinocyst zonation in the eastern North Sea Basin, Denmark. Review of Palaeobotany and Palynology 161, 1-29. https://doi.org/10.1016/j.revpalbo.2010.02.005.

Eidvin, T. 2009: A biostratigraphic, strontium isotopic and lithostratigraphic study of the upper part of Hordaland Group and lower part of Nordland Group in well 34/7-2, 34/7-12 and 34/7-R-1 $\mathrm{H}$ from the Tordis Field in the Tampen area (northern North Sea). Norwegian Petroleum Directorate, 1-27. http://www.npd.no/Global/Norsk/3\%20-\%20Publikasjoner/ Forskningsartikler/Tordis-biostr-rapp.pdf.
Eidvin, T. 2016: Biostratigraphy and Strontium Isotope Stratigraphy (SIS) of Lower Oligocene to Pleistocene in Well 9/09-A 23 (Bruce Field, UK) including Hutton sand (informal). Norwegian Petroleum Directorate, 1-15.

http://www.npd.no/Global/Norsk/3-Publikasjoner/ Forskningsartikler/9-09a-A23-figurer.pdf.

Eidvin, T. \& Rundberg, Y. 2001: Late Cainozoic stratigraphy of the Tampen area (Snorre and Visund fields) in the northern North Sea, with emphasis on the chronology of early Neogene sands. Norwegian Journal of Geology 81, 119-160. http://www.npd.no/Global/Norsk/3\%20-\%20Publikasjoner Forskningsartikler/Eidvin_and_Rundberg_2001.pdf.

Eidvin, T. \& Rundberg, Y. 2007: Post-Eocene strata of the southern Viking Graben, northern North Sea; intergrated biostratigraphic, strontium isotopic and lithostratigraphic study. Norwegian Journal of Geology 87, 391-450.

http://www.npd.no/Global/Norsk/3-Publikasjoner/ Forskningsartikler/Eidvin_and_Rundberg_2007.pdf.

Eidvin, T. \& Rundberg, Y. 2016a: Taler for turbiditter og åpent hav. http://www.geoforskning.no/nyheter/grunnforskning/1160-talerfor-turbidittstrommer-og-apent-hav. (Accessed 25.08.2019).

Eidvin, T. \& Rundberg, Y. 2016b: Sedimentene og fossilene gir svar. http://www.geoforskning.no/nyheter/olje-og-gass/1187sedimentene-og-fossilene-gir-svar. (Accessed 25.09.2019).

Eidvin, T. \& Øverland, J.A. 2009: Faulty geology halts project. Norwegian Continental Shelf 2, 35-36.

http://www.npd.no/global/engelsk/3\%20-\%20publications/ norwegian\%20continental\%20shelf/pdf/10\%20faulty\%20geology.pdf.

Eidvin, T., Koç, N., Smelror, M. \& Jansen, E. 1998: Biostratigraphical investigations of borehole 6704/12-GB1 from the Gjallar Ridge on the Vøring Plateau. Report for the Seabed Project OD-98-22, 29 pp. http://www.npd.no/engelsk/cwi/pbl/wdss_old/3759_01_ Investigation_6704-12-GB1.pdf.

Eidvin, T., Riis, F. \& Rundberg, Y. 1999: Upper Cainozoic stratigraphy in the central North Sea (Ekofisk and Sleipner fields). Norwegian Journal of Geology 79, 97-127. https://doi.org/10.1080/002919699433843.

Eidvin, T., Bugge, T. \& Smelror, M. 2007: The Molo Formation, deposited by coastal progradation on the inner Mid-Norwegian continental shelf, coeval with the Kai Formation to the west and the Utsira Formation in the North Sea. Norwegian Journal of Geology 87, 75-142.:

http://www.npd.no/Global/Norsk/3-Publikasjoner/ Forskningsartikler/Eidvin_et_al_2007.pdf.

Eidvin, T., Rasmussen, E.S., Riis, F. \& Rundberg, Y. 2010: Oligocene to Lower Pliocene deposits of the Norwegian continental shelf, with correlation to the Norwegian Sea, Greenland, Svalbard, Denmark and their relation to the uplift of Fennoscandia. Norwegian Geological Society, Abstracts and proceedings of the $29^{\text {th }}$ Nordic Geological Winter Meeting, 11-13 January, Oslo, p. 43-44.

Eidvin, T., Riis, F., Rasmussen, E.S. \& Rundberg, Y. 2013: Investigation of Oligocene to Lower Pliocene deposits in the Nordic area. Norwegian Petroleum Directorate Bulletin 10, 1-62. http://www.npd.no/engelsk/cwi/pbl/NPD_papers/Hyperlink-NPDBulletin-10.pdf.

Eidvin, T., Ullmann, C.V., Dybkjær, K., Rasmussen, E.S. \& Piasecki, S. 2014a: Discrepancy between Sr isotope and biostratigraphic datings of the upper middle and upper Miocene successions (eastern North Sea Basin, Denmark). Palaeogeography, Palaeoclimatology, Palaeoecology 411, 267-280. https://doi.org/10.1016/j.palaeo.2014.07.005.

Eidvin, T., Riis, F. \& Rasmussen, E.S. 2014b: Correlation of Upper Oligocene to Lower Pliocene deposits of the Norwegian continental shelf, Norwegian Sea, Svalbard, Denmark and their relation to the uplift of Fennoscandia: a synthesis. Marine and Petroleum Geology 56, 184-221. https://doi.org/10.1016/j.marpetgeo.2014.04.006.

Eldrett, J.S, Harding, I.C., Wilson, P.A., Butler, E. \& Roberts, A.P. 2007: Continental ice in Greenland during the Eocene and Oligocene. Nature 446, 176-179. https://doi.org/10.1038/nature05591. 
Erlström, M. 1994: Evolution of Cretaceous sedimentation in Scania. Lund Publication in Geology 122, 1-37.

Esteban, M., Braga, J.C. \& Santisteban, C. 1996: Western Mediterranean reef complexes. In Franseen, E.K., Esteban, M., Ward, W.C. \& Rouchy, J.M. (eds.): Models for Carbonate Stratigraphy from Miocene Reef Complexes of Mediterranean Regions, Society of Economic Paleontologists and Mineralogists, Concepts in Sedimentology and Paleontology 5, pp. 55-72. https://doi.org/10.2110/csp.96.01.0055.

Fronval, T. \& Jansen, E. 1996: Late Neogene paleoclimates and paleoceanography in the Iceland-Norwegian Sea: evidence from the Iceland and Vøring Plateaus. In Thiede, J., Myhre, A.M., Firth, J.V., John, G.L. \& Ruddiman, W.F. (eds.): Proceedings of the Ocean Drilling Program, Scientific Results 151: College Station, TX (Ocean Drilling Program), pp. 455-468.

https://doi.org/10.2973/odp.proc.sr.151.134.1996.

Gibbard, P. 2007: Europe cut adrift. Nature 448, 259-260. https://doi.org/10.1038/448259a.

Gibbard, P. \& Cohen, K.M. 2015: Quaternary evolution of the North Sea and the English Channel. Proceedings of the Open University Geological Society 1, 63-74.

Gjeldvik, I.T., Eidvin, T. \& Riis, F. 2011: Neogene Delta Sytems in the North-Western North Sea. Poster at the conference "Sustainable Earth Sciences" organized by European Association of Geoscientists and Engineers (EAGE), Valencia 8-10 November 2011.

Gradstein, F., Ogg, J. \& Smith, A. 2004: A Geological Time Scale. Cambridge University Press, Cambridge, U.K.

Gregersen, U. \& Johannessen, P.N. 2007: Distribution of the Neogene Utsira Sand and Hutton Sand, and the succeeding deposits in the Viking Graben area, North Sea. Marine and Petroleum Geology 24, 591-606. https://doi.org/10.1016/j.marpetgeo.2007.04.006.

Grøsfjeld, K., Dybkjær, K., Eidvin, T., Riis, F., Rasmussen, E.S. \& Knies, J. 2019: New age constraints on the Molo Formation on the Norwegian shelf west of Vestfjorden (Nordland Ridge). Norwegian Journal of Geology 99, 1-XX.

Gürs, K. \& Jansen, A.W. 2002: Revised Pteropod Biostratigraphy for the Miocene of the North Sea Basin. In Gürs, K. (ed.): Northern European Cenozoic Stratigraphy, Proceedings of the $8^{\text {th }}$ Biannual Meeting RCNNS/RCNPS, Flintbek, pp. 117-131.

Halland, E.K., Bjørnstad, A., Magnus, C., Riis, F., Meling, I.M., Gjeldvik, I.T., Tappen, I.M., Mujezinovic, J., Bjørheim, M., Rød, R.S. \& Pham, V.T.H. 2011 (updated 2019): $\mathrm{CO}_{2}$ Storage Atlas, Norwegian North Sea.

https://www.npd.no/fakta/publikasjoner/atlas/co2-lagringsatlasfor-nordsjoen/ (25.09.2019).

Hansen, J.P.V. \& Rasmussen, E. 2008: Distribution and thicknesses of reservoir sands in a wave-dominated delta, Billund delta, eastern Danish North Sea and Jylland. Sedimentary Research 78, 130-146. https://doi.org/10.2110/jsr.2008.010.

Hardenbol, J., Thierry, J., Farley, M.B., Jacquin Th., de Graciansky, P.C. \& Vail, P.R. 1998: Mesozoic and Cenozoic sequence chronostratigraphic framework of European basins. Society for Sedimentary Geology Special Publication 60, 1-30. https://doi.org/10.2110/pec.98.02.0003.

Van Houten, F.B. \& Purucker, M.E. 1984: Glauconitic Peloids and Chamositic Ooids - Favourable Factors, Constraints, and Problems. Earth-Science reviews 20, 211-243.

Houthuys, R. 2014: A reinterpretation of the Neogene emersion of central Belgium based on the sedimentary environment of the Diest Formation and the origin of the drainage pattern. Geologica Belgica 17, 211-235.

Howarth, R.J. \& McArthur, J.M. 1997: Statistics for Strontium Isotope Stratigraphy: A Robust LOWESS Fit to Marine Sr isotope Curve for 0 to $206 \mathrm{Ma}$, with Look-up table for Derivation of Numeric Age. Journal of Geology 105, 441-456. https://doi.org/10.1086/515938.
Howarth, R.J. \& McArthur, J.M. 2004: Strontium Isotope Stratigraphy. In F.M. Gradstein \& J.G. Ogg (eds.): A Geological Time Scale, with Look-up Table Version 4: 08/04, Cambridge University Press, Cambridge, U.K., pp. 96-105.

https://doi.org/10.1017/CBO9780511536045.008.

Jansen, E. \& Sjøholm, J. 1991: Reconstruction of glaciation over the past 6 Myr from ice-borne deposits in the Norwegian Sea. Nature 349, 600-603. https://doi.org/10.1038/349600a0.

Japsen, P. 1993: Influence of lithology and Neogene uplift on seismic velocities in Denmark; implications for depth conversion of maps. American Association of Petroleum, Bulletin 77, 194-211. https://doi.org/10.1306/BDFF8BC8-1718-11D7-8645000102C1865D.

King, C. 1983: Cenozoic micropaleontological biostratigraphy of the North Sea. Report of the Institute for Geological Sciences 82, $40 \mathrm{pp}$.

King, C. 1989: Cenozoic of the North Sea. In Jenkins, D.G. \& Murray, J.W. (eds.): Stratigraphical Atlas of Fossils Foraminifera, pp. 418-489.

Knox, R., Bosch, A., Slodkowska, B., Standke, G., Vandenberghe, N. 2010: Cenozoic. In Doornenbal, J.C. \& Stevenson, A.G. (eds.): Petroleum Geological Atlas of the Southern Permian Basin Area, Houten European Association of Geoscientists \& Engineers Publications, 211-223.

Kuhlmann, G., Langereis, C., Munsterman, D., van Leeuwen, R.J., Verreussel, R., Meulenkamp, J. \& Wong, T. 2006: Chronostratigraphy of Late Neogene sediments in the southern North Sea Basin and paleoenvironmental interpretations. Palaeogeography, Palaeoclimatology, Palaeoecology 239, 426-455. https://doi.org/10.1016/j.palaeo.2006.02.004.

Laberg, J.S., Dahlgren, K.I.T. \& Vorren, T.O. 2005: The Eocene-late Pliocene paleoenvironment in the Vøring Plateau area, Norwegian Sea paleoceanographic implications. Marine Geology 214, 269-285. https://doi.org/10.1016/j.margeo.2004.10.031.

Larsen, G. \& Dinesen, A. 1959: Vejle Fjord Formation ved Brejning: Sedimenterne og foraminiferfaunaen (Oligocæn - Miocæn). Geological Survey of Denmark II, Rokke 82, 1-114.

Larsson, L.M., Vajda, V. \& Dybkjær, K. 2010: Vegetation and climate in the latest Oligocene-earliest Miocene in Jylland, Denmark. Review of Palaeobotany and Palynology 159, 166-176.

Larsson, L.M., Dybkjær, K., Rasmussen, E.S., Piasecki, S., Utescher, T. \& Vajda, V. 2011: Miocene climate evolution of northern Europe: A palynological investigation from Oligocene-earliest Miocene in Jylland, Denmark. Review of Palaeobotany and Palynology Fennoscandian Border Zone in Denmark. Tectonophysics 137, 21-29. https://www.academia.edu/12971219/Miocene_climate_ evolution_of_northern_Europe_A_palynological_investigation_ from Denmark.

Laursen, G.V. \& Kristoffersen, F.N. 1999: Detailed foraminiferal biostratigraphy of Miocene formations in Denmark. Geology 36, 73-107.

Løseth, H. 2016: En global miocen hendelse i Nordsjøen. http://www.geoforskning.no/nyheter/olje-og-gass/1172-en-globalmiocen-hendelse-i-nordsjoen (25.09.2019)

Løseth, H. \& Henriksen, S. 2005: A Middle to Late Miocene compression phase along the Norwegian passive margin. In Doré, A.G. \& Vining, B.A. (eds.): Petroleum Geology: North-West Europe and Global Perspectives, Proceedings of the 6th Petroleum Geology Conference, pp. 845-859. https://doi.org/10.1144/0060845.

Løseth, H. \& Øygarden, B. 2016: Verdens største sandvulkan eller en turbidittsand?

http://www.geoforskning.no/nyheter/olje-og-gass/1149-verdensstorste-sandvulkan-eller-en-turbidittsand (25.09.2018).

Løseth, H., Raulline, B. \& Nygård, A. 2013: Late Cenozoic geological evolution of the northern North Sea: development of a Miocene unconformity reshaped by large-scale Pleistocene sand intrusion. Journal of the Geological Society 170, 133-145. https://doi.org/10.1144/jgs2011-165. 
Løseth, H., Kyrkjebø, R., Hilde, E., Wild, R.J. \& Bunkholt, H. 2016a: $400 \mathrm{~m}+$ of rapid sea level rise along an inner passive margin seismic observation from the Pliocene Molo Formation, mid Norway. Norwegian Geological Society, Abstract and Proceedings 1, 53-54.

Løseth, H., Øygarden, B., Nygård, A. \& Raulline, B. 2016b: Reply to Discussion on "Late Cenozoic geological evolution of the northern North Sea: development of a Miocene unconformity reshaped by large-scale Pleistocene sand intrusion". Journal of the Geological Society 173, 394-397. https://doi.org/10.1144/jgs2015-104.

Løseth, H., Kyrkjebø, R., Hilde, E., Wild, R.J. \& Bunkholt, H. 2017: 500 $\mathrm{m}$ of rapid base level rise along an inner passive margin - Seismic observations from the Pliocene Molo Formation, mid Norway. Marine and Petroleum Geology 86, 268-287. https://doi.org/10.1016/j.marpetgeo.2017.05.039.

Miller, K.G., Mountain, G.S., Browning, J.V., Kominz, M.A., Sugarman, P.J., Christie-Blick, N., Katz, M.E. \& Wright, J.D. 1998: Cenozoic global sea level, sequences and the New Jersey transect: results from coastal plain and continental slope drilling. Review of Geophysics 36, 569-601.

Miller, K.G., Kominz, M.A., Browning, J.V., Wright, J.D., Mountain, G.S., Katz, M.E., Sugarman, P.J., Cramer, B.S., Christie-Blick, N. \& Pekar, S.F. 2005: The Phanerozoic record of global sea-level change. Science 310, 1293-1298. https://doi.org/10.1126/science.1116412.

Mogensen, T.E. \& Korstgård, J. 1993: Structural development and trap formation along the Børglum Fault, Tornquist Zone, Denmark, and a comparison with the Painted Canyon Fault, San Andreas Zone, USA. In Spencer, A.M. (ed.): Generation, Accumulation and Production of Europe's hydrocarbons III, Springer Verlag, Berlin, pp. 89-97. https://doi.org/10.1007/978-3-642-77859-9_8.

Moran, K., Backman, J., \& The IODP Expedition 302 Science Party, 2006: A Cenozoic History of the Arctic Ocean. Oceanography 19, 162-167. https://doi.org/10.5670/oceanog.2006.14.

Müller, C. \& Spiegler, D. 1993: Revision of the late/middle Miocene boundary on the Voering Plateau (ODP Leg 104). Newsletter on Stratigraphy 28, 171-178. https://doi.org/10.1127/nos/28/1993/171.

Møller, L.K., Rasmussen, E.S. \& Clausen, O.R., 2009: Clinoform migration patterns of a Late Miocene delta complex in the Central Graben; implications for relative sea-level changes. In Henriksen, S., Hampson, G.J., Helland-Hansen, W., Johannessen, E.P. \& Steel, R.J. (eds.): Trajectory Analysis in Stratigraphy, Basin Research, 21, pp. 704-720. https://doi.org/10.1111/j.1365-2117.2009.00413.x.

Nielsen, S.B., Thomsen, E., Hansen, D.L. \& Clausen, O.R. 2005: Plate-wide stress relaxation explains European Palaeocene basin inversions. Nature 435,195-198. https://doi.org/10.1038/nature03599.

Odin, G.S. \& Matter, A. 1981: De glauconiarum origine. Sedimentology 28, 611-641. https://doi.org/10.1111/j.1365-3091.1981.tb01925.x.

Olesen, O., Gellein, J., Gernigon, L., Kihle, O., Koziel, J., Lauritsen, T., Mogaard, J.O., Myklebust, R., Skilbrei, J.R. \& Usov, S. 2010: Magnetic anomaly map, Norway and adjacent areas, scale 1:3,000,000, Geological Survey of Norway.

Olivarius, M. 2009: Provenance and facies of Miocene sand succession in western Denmark based on bulk geochemistry, heavy minerals and zircon dating. MSc. Thesis, Department of Geography and Geology, University of Copenhagen.

Overeem, I., Weltje, G.J., Bishop-Kay, C. \& Krooenenberg, S.B. 2014: The Late Cenozoic Eridanos delta system in the Southern North Sea Basin: a climate signal in the sediment supply? Basin Research 13, 293-312. https://doi.org/10.1046/j.1365-2117.2001.00151.x.

Patruno, S., Scisciani, V., Helland-Hansen, W., D’Intino, N., Reid, W. \& Pellegrini, C. 2019 (early view): Upslope-climbing shelf-edge clinoforms and the stepwise evolution of the northern European glaciation (lower Pleistocene Eridanos Delta system, UK North Sea): When sediment supply overwhelms accommodation. Basin Research, 1-16. https://doi.org/10.1111/bre.12379.
Pérez-Asensio, J.N., Aquirre, J., Jiménez-Moreno, G., Schmiedl, G. \& Civis, J. 2013: Glacioeustatic control on the origin and cessation of the Messinian salinity crisis. Global and Planetary Change 111, 1-8. https://doi.org/10.1016/j.gloplacha.2013.08.008.

Pound, M.J. \& Riding, J.B. 2015: Palaeoenvironment, palaeoclimate and age of the Brassington Formation (Miocene) of Derbyshire, UK. Journal of the Geological Society 173, 306-309. https://doi.org/10.1144/jgs2015-050.

Quale, G. \& Spiegler, D. 1989: The stratigraphic significance of Bolboforma (Algae, Chrypsophyta) in Leg 104 samples from the Vøring Plateau. In Eldholm, O., Thiede, J. \& Tayler, E. (eds.): Proceedings of the Ocean Drilling Program, Scientific Results 104, College Station, TX (Ocean Drilling Program), pp. 487-495.

Rasmussen, E.S. 2004: The interplay between true eustatic sea-level changes, tectonics, and climate changes: what is the dominating factor in sequence formation of the Upper Oligocene-Miocene succession in the eastern North Sea Basin, Denmark? Global and Planetary Change 41, 15-30. https://doi.org/10.1016/j.gloplacha.2003.08.004.

Rasmussen, E.S. 2009: Neogene inversion of the north-eastern North Sea. Tectonophysic 465, 84-97.

Rasmussen, E.S. 2013: Cenozoic structures in the North Sea Basin A case for salt tectonics: Discussion. Tectonophysics 601, 226-233. https://doi.org/10.1016/j.tecto.2012.10.038.

Rasmussen, E.S. 2017: Sedimentology and sequence stratigraphy of the uppermost upper Oligocene - Miocene fluvio-deltaic system in the eastern North Sea Basin: the influence of tectonism, eustacy and climate. Unpublished $\mathrm{PhD}$ thesis, University of Copenhagen, $67 \mathrm{pp}$ +15 Papers.

Rasmussen, L.B. 1966: Biostratigraphical studies of the marine younger Miocene of Denmark. Based on the molluscan faunas. Geological Survey of Denmark, II Rakke, 358 pp.

Rasmussen, E.S. \& Dybkjær, K. 2005: Sequence stratigraphy of the Upper Oligocene - Lower Miocene of eastern Jylland, Denmark: role of structural relief and variable sediment supply in controlling sequence development. Sedimentology 52, 25-63. https://doi.org/10.1111/j.1365-3091.2004.00681.x.

Rasmussen, E.S. \& Dybkjær, K. 2014: Patterns of Cenozoic sediment flux from western Scandinavia: discussion. Basin Research 26, 338346. https://doi.org/10.1111/bre.12024.

Rasmussen, E.S., Vejbæk, O.V., Bidstrup, T., Piasecki, S. \& Dybkjær, K. 2005: Late Cenozoic depositional history of the Danish North Sea Basin: implications for the petroleum systems in the Kraka, Halfdan, Siri and Nini fields. In Dore, A.G. \& Vinding, B.A. (eds.): Petroleum geology: North-West Europe and global perspectives, Proceedings of the $6^{\text {th }}$ petroleum geology conference, Geological Society of London, pp. 1347-1358. https://doi.org/10.1144/0061347.

Rasmussen, E.S., Heilmann-Clausen, C., Waagstein, R. \& Eidvin, T. 2008: The Tertiary of Norden. Episodes 21, 66-72. https://doi.org/10.18814/epiiugs/2008/v31i1/010.

Rasmussen, E.S., Dybkjær, K. \& Piasecki, S. 2010: Lithostratigraphy of the Upper Oligocene - Miocene Succession of Denmark. Geological Survey of Denmark and Greenland Bulletin 22, pp. $92+9$ plates.

Riis, F. \& Eidvin, T. 2015: Structures formed by mobilization of sand in the Miocene Utsira and Skade formations in the North Sea. Geometries, timing and possible mechanisms. 31 $1^{\text {st }}$ Geological Winter Meeting, Abstract and Proceedings of the Geological Society of Norway, 12-14 January, Stavanger, Norway, p. 81.

Riis, F. \& Eidvin, T. 2016: The Scandinavian highlands and Miocene to Pliocene sea levels. Bulletin of the The Geological Society of Finland, Special Volume, Abstract of The $32^{\text {nd }}$ Nordic Geological Winter Meeting, 13th-15th January 2016, Helsinki, Finland, p. 255-256.

Rundberg, Y. \& Eidvin, T. 2005: Controls on depositional history and architecture of the Oligocene-Miocene succession, northern North Sea Basin. In B.T.G. Wandaas et al. (eds.): Onshore-Offshore Relationships on the North Atlantic Margin, Norwegian Petroleum Society Special Publication 12, pp. 207-239. https://doi.org/10.1016/S0928-8937(05)80050-5. 
Rundberg, Y. \& Eidvin, T. 2016a: Discussion on Late Cenozoic geological evolution of the northern North Sea: development of a Miocene unconformity reshaped by large-scale Pleistocene sand intrusion. Journal of the Geological Society 173, 384-393.

https://doi.org/10.1144/jgs2014-023.

Rundberg, Y. \& Eidvin, T. 2016b: Diskusjon om sandinjeksjon i Nordsjøen.

http://www.geoforskning.no/nyheter/olje-og-gass/1132-diskusjonom-sandinjeksjon-i-nordsjoen-2 (25.09.2019).

Sanjeev, G., Collier, J.S., Palmer-Felgate, A. \& Potter, G. 2007: Catastrophic flooding origin of shelf valley systems in the English Channel. Nature 448, 342-345.

https://doi.org/10.1038/nature06018.

Sliwinska, K.K., Dybkjær, K., Schoon, P., Beyer, C., King, C., Schouten, S. \& Nielsen, O.B. 2014: Paleoclimatic and paleoenvironmental records of the Oligocene-Miocene transition, central Jylland, Denmark. Marine Geology 350, 1-15. https://doi.org/10.1016/j.margeo.2013.12.014.

Spiegler, D. 1999: Bolboforma Biostratigraphy From The HattonRockall Basin (North Atlantic). In Raymo, M.E., Jansen, E., Blum, P. \& Herbert, T.D. (eds.): Proceedings of the Ocean Drilling Program, Scientific Results, Vol 162: College Station, TX (Ocean Drilling Program), pp. 35-49. https://doi.org/10.2973/odp.proc.sr.162.013.1999.

Spiegler, D. \& Jansen, E. 1989: Planktonic Foraminifer Biostratigraphy of Norwegian Sea Sediments: ODP Leg 104. In Eldholm, O., Thiede, J. \& Tayler, E.(eds.): Proceedings of the Ocean Drilling Program, Scientific Results 104: College Station, TX (Ocean Drilling Program), pp. 681-696.

https://doi.org/10.2973/odp.proc.sr.104.157.1989.

Spiegler, D. \& Müller, C. 1992: Correlation of Bolboforma zonation and nannoplankton stratigraphy in the Neogene of the North Atlantic: DSDP sites 12-116, 49-408, 81-555 and 94-608. Marine Micropaleontology 20, 45-58.

https://doi.org/10.1016/0377-8398(92)90008-8.

St. John, K. 2008: Cenozoic ice-rafting history of the central Arctic Ocean: Terrigenous sands on the Lomonosov Ridge. Paleoceanography 23, 1-12. https://doi.org/10.1029/2007PA001483.

Sørensen, J.C., Gregersen, U., Breiner, M. \& Michelsen, O. 1997: Highfrequency sequence stratigraphy of Upper Cenozoic deposits in the central and southeastern North Sea Areas. Marine and Petroleum Geology 14, 99-123.

https://doi.org/10.1016/S0264-8172(96)00052-9.

Thybo, H. 2001: Crustal structure along the EGT profile across the Tornquist Fan interpreted from seismic, gravity and magnetic data. Tectonophysics 334, 155-190.

https://doi.org/10.1016/S0040-1951(01)00055-5.

Utescher, T., Mosbrugger, V., Ivanov, D. \& Dilcher, D.L. 2009: Presentday climatic equivalents of European Cenozoic climates. Earth and Planetary Science Letters 284, 544-552. https://doi.org/10.1016/j.epsl.2009.05.021.

Vandenberghe, N., Harris, W.B., Wampler, J.M., Houthuys, R., Louwye, S., Adrianes, R., Vos, K., Lanckacker, T., Matthijs, J., Deckers, J., Verhaegen, J., Laga, P., Westerhoff, W. \& Munsterman, D. 2014: The implications of K-Ar glauconite dating of the Diest Formation on the paleogeography of the Upper Miocene in Belgium. Geologica Belgica 17, 161-174.

Vejbæk, O.V. \& Andersen, C. 1987: Cretaceous-Early Tertiary inversion tectonism in the Danish Central Trough. Tectonophysics 137, 221238. https://doi.org/10.1016/0040-1951(87)90321-0.

Zachos, J., Pagani, M., Sloan, L., Thomas, E. \& Billups, K. 2001: Trends, Rhythms, and Aberrations in Global Climate 65 Ma to Present. Science 292, 686-693. https://doi.org/10.1126/science.1059412.

Ziegler, P.A. 1982: Geological atlas of Western and Central Europe. Elsevier, Amsterdam, $130 \mathrm{pp}$.

Ziegler, P.A. 1990: Geological Atlas of Western and Central Europe. Shell Internationale Petroleum Maatschappij B.V., 239 pp. 